\title{
The Permian-Triassic transition and the onset of Mesozoic sedimentation at the northwestern peri-Tethyan domain scale: Palaeogeographic maps and geodynamic implications
}

\author{
Sylvie Bourquin ${ }^{\mathrm{a}, *}$, Antoine Bercovici ${ }^{\mathrm{a}}$, José López-Gómez ${ }^{\mathrm{b}}$, José B. Diez ${ }^{\mathrm{c}}$, Jean Broutin a, Ausonio Ronchi ${ }^{\mathrm{e}}$, \\ Marc Durand ${ }^{\mathrm{f}}$, Alfredo Arché ${ }^{\mathrm{b}}$, Bastien Linol ${ }^{\mathrm{a}, \mathrm{g}}$, Frédéric Amour ${ }^{\mathrm{a}, \mathrm{h}}$ \\ a UMR 6118 (CNRS/INSU), Géosciences Rennes, Université de Rennes 1, Campus de Beaulieu, 35042 Rennes Cedex, France \\ ${ }^{b}$ Instituto de Geología Económica (CSIC-UCM), Facultad de Geologia, Universidad Complutense, C/Antonio Novais 2, 28040 Madrid, Spain \\ c Departamento Geociencias Marinas y Ordenacio'n del Tenitorio, Universidad de Vigo, Campus Lagoas-Marcosende, 36200 Vigo (Pontevedra), Spain

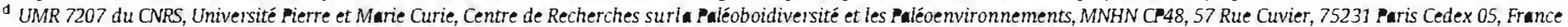 \\ e Dipartimento di Scienze della Terra, Universitì di Pavia, Via Ferrata 1, 27100, Pavia, Italy \\ 47 rue de Lavax, 54520 Laxou, France \\ * University of Cape Town, Geological Department, Cape Town, South Africa \\ ${ }^{n}$ Unstitut für Geowissenchaften Kari-Liebknecht-Strasse 24, Haus 27, 14476 Potsdam, Gernany
}

Keywords:

Middle-l.ate Permian

Early-Middle Triassic

Permian-Triassic Boundary

NW peri-Tethyan domain

Palaeogeographic maps

\begin{abstract}
A B S T R A C T
The main aim of this paper is to review Middle Permian through Middle Triassic continental successions in European. Secondly, areas of Middle-Late Permian sedimentation, the Permian-Triassic Boundary (PTB) and the onset of Triassic sedimentation at the scale of the westernmost peri-Tethyan domain are defined in order to construct palaeogeographic maps of the area and to discuss the impact of tectonics, climate and sediment supply on the preservation of continental sediment.

At the scale of the western European peri-Tethyan basins, the Upper Permian is characterised by a general progradational pattern from playa-lake or floodplain to fluvial environments. In the northern Variscan Belt domain, areas of sedimentation were either isolated or connected to the large basin, which was occupied by the Zechstein Sea. In the southern Variscan Belt, during the Late Permian, either isolated endoreic basins occurred, with palaeocurrent directions indicating local sources, or basins underwent erosion and/or there was no deposition. These basins were not connected with the Tethys Ocean, which could be explained by a high border formed by Corsica-Sardinia palaeorelief and even parts of the Kabilia microplate. The palaeoflora and sedimentary environments suggest warm and semi-arid climatic conditions.

At the scale of the whole study area, an unconformity (more or less angular) is observed almost everywhere between deposits of the Upper Permian and Triassic, except in the central part of the Germanic Basin. The sedimentation gap is more developed in the southern area where, in some basins, Upper Permian sediment does not occur. The large sedimentary supply, erosion and/or lack of deposition during the Iate Permian, as well as the variable palaeocurrent direction pattern between the Middle-late Permian and the EarlyTriassic indicate a period of relief rejuvenation during the Iate Permian. During the Induan, all the intra-belt basins were under erosion and sediment was only preserved in the extra-belt domains (the northern and extreme southern domains). In the northern domain (the central part of the Germanic Basin), sediment was preserved under the same climatic conditions as during the latest Permian, whereas in the extreme southern domain, it was probably preserved in the Tethys Ocean, implying a large amount of derital components entering the marine waters. Mesozoic sedimentation began in the early Olenekian; the ephemeral fluvial systems indicate arid climatic conditions during this period. Three distinct areas of sedimentation occur: a northern and southern domain, separated by an intra-belt domain. The latter accumulated sediments during the Early-Middle Permian and experienced erosion and/or no-deposition conditions between the Middle-Iate Permian and the beginning of Mesozoic sedimentation, dated as Anisian to Hettangian. At the top of the Lower Triassic, another tectonically induced, more or less angular unconformity is observed: the Hardegsen unconformity, which is dated as intra-Spathian and is especially found in the North European basins. This tectonic activity created new source areas and a new fluvial style, with marine influences at the distal part of the systems. During the Anisian and Ladinian, continental sedimentation was characterised by a
\end{abstract}

\footnotetext{
* Corresponding author. Fax: +33223236100.

E-mail address: sylvie.bourquin@univ-rennes1.fr (S. Bourquin).
} 
retrogradational trend. In other words, the fluvial system evolved into fluvio-marine environments, attesting to a direct influence of the Tethys Ocean in the southern and northem domains. Both at the end of the Olenelian (Spathian) and during the Anisian, the presence of palaeosols, micro- and macrofloras indicate less arid conditions throughout this domain.

\section{Introduction}

In the supercontinent of Iaurasia, the Appalachian-Variscan Belt separates intra-Variscan basins and basins in the former Variscan foreland (Ziegler, 1982, 1990). This Appalachian-Variscan mountain range seems to represent the limit of the influence of the Tethys Ocean on the basins located to the north (Fluteau et al., 2001). At the scale of the western European peri-Tethyan basins, the uppermost part of the Palaeozoic and lowermost part of the Mesozoic consist of continental redbeds. A "Permian-Triassic" age has often been proposed for this lithostratigraphic unit, despite a total lack of biostratigraphical data. In most cases, the lack of any Early Triassic biochronological evidence makes it very difficult to attribute these basal beds to either the Permian or Triassic period.

Throughout the northern hemisphere, where continuity can be demonstrated between the Permian and Triassic, there is no evidence for a sudden collapse of terrestrial ecosystems. Rather, the climate seems to have evolved towards more humid conditions during the Griesbachian (e.g. Fuglewicz, 1980; Kozur, 2003); the macroflora continues to exhibit a predominantly Permian character, whereas the palynoflora is transitional (Lozovsky et al., 2001; Shu and Norris, 1999).

Within the continental northwestem Tethyan domain, the PernianTriassic Boundary (PTB) corresponds to an unconformity, except locally in the Germanic Basin (Bourquin et al., 2007; Durand, 2006). At the scale of European basins, the Permian successions are mainly characterised by playa-lake or fluvio-lacustrine deposits, in some cases dated by palynology. In these continental series, the difficulty is to constrain the stratigraphic age. Actually, the subdivisions in the study area are mainly lithological: "Zechstein" in Germany, based on a sedimentological facies (Richter-Bernburg, 1955) and "Thuringian" in France, based on palaeoflora facies (Renevier, 1874). The Zechstein corresponds to the Late Permian, but the "Thuringien" facies is Middle-Late Permian. It is for this reason that Middle-Late Permian sediments are considered in this paper. Moreover, the onset of Mesozoic sedimentation is diachronous at the scale of the northwestern peri-Tethyan area. Beyond the Germanic Basin and in some basins in England, for which palynology and magnetos atigraphic data are available, the boundary cannot be precisely dated due to the total absence of any biostratigraphic markers in the earliest fluvial deposits overlying the pre-Triassic unconformity. There, the oldest Mesozoic fossils are Anisian in age (Middle Triassic). The oldest undated fluvial deposits, found above the Permian-Triassic unconformity, are interbedded with aeolian deposits or include indicators of aridity, such as ventifacts or the reworking of aeolian deposits (Bourquin et al., 2007; Durand, 2006). Within the Germanic Basin, the single time interval of a warm and arid climate is attributed to the Volpriehausen Formation, dated as early Olenekian (Smithian) by magnetostratigraphy (Kozur and Bachmann, 2008; Szurlies, 2007). This arid episode was previously dated as late Dienerian/early Smithian (Cassinis et al., 2007; Durand, 2006, 2008) according to the first magnetostratigraphic age (Szurlies, 2004). This arid episode within European basins suggests continental-scale arid conditions (Bourquin et al., 2007; Cassinis et al., 2007; Durand, 2006). Moreover, palaeoclimate simulations based on different palaeogeographic scenarios for this period also support very arid conditions in the sedimentary basins, with the water supply and associated sediment coming from the adjacent relief, i.e. remnants of the Hercynian (Variscan)-Appalachian Mountains (Bourquin et al., 2006; Péron et al., 2005). Consequently, a careful recognition of the unconformities and the use of sedimentary indicators of climatic conditions can constitute powerful tools to establish correlations in the corresponding series (Bourquin et al, 2007, 2009; Durand, 2006).

Based on a review of Permian-Triassic successions, the aims of this paper are to define the areas in which Middle-Late Permian sedimentation occurred, to locate the stratigraphic position of the Permian-Triassic unconformity and the onset of Triassic sedimentation at the scale of the westernmost Tethyan domain (Fig. 1). A second objective is the constuction of palaeogeographic maps of the area, which will allow discussion of the impact of tectonics, climate and sediment supply on continental sediment accumulation and preservation.

\section{Middle Permian-Ladinian evolution of the northwestern peri-Tethyan domain}

\subsection{Middle-Late Permian}

Based on a review of European basin successions during the Middle-Upper Permian (Fig. 1), the aim is to define the areas in which sediment was accumulating or undergoing erosion during this period. These results are summarised in Figs. 2-4.

Within the Germanic Basin, the Middle Permian is composed of the Upper Rotliegend II Formation, a saline lake deposit attributed to Wordian-Wuchiapingian age (Legler and Schneider, 2008). This formation passes upwards into transgressive marine carbonates and mudstones at the base of the Zechstein deposits (Fig. 2), followed by evaporites deposited from marine incursions coming from the presentday Barents Sea (Legler and Schneider, 2008; Ziegler, 1990). Towards the end of the Permian, the connection with the Barents Sea was interrupted by a strong clastic influx in the area of the Viling-Central Graben system (Geluk, 2005; Ziegler, 1990). The basin evolved into an extensive sabkha, with isolated saline ponds in the depocentral area that are laterally related to braided rivers at its margins, and later into extensive inland playa-lakes (Aigner and Bachmann, 1992; Geluk, 2005). In northwest Germany, conchostraceans, palaeomagnetic and palynologic data allowed the top of the Permian to be placed, characterised by grey siltstones and shales of lake environments, within the base of the Calvörde Formation, at the top of the "Graubankbereich" (Fig. 2; Geluk, 2005;Geluk and Röhling, 1997; Kozur, 1998; Szurlies et al., 2003). Therefore, the Permian-Triassic Boundary (PTB) would be located $20 \mathrm{~m}$ above the typical Zechstein deposits (Szurlies, 2007; Szurlies et al., 2003). In the Netherlands (Fig. 1), the uppermost Permian is represented by the Zechstein Upper Claystone Formation, which occurs throughout the country and unconformably overlies older deposits of the Lower Zechstein and even may rest on the Upper Rotliegend Group (Geluk, 1998, 2005). This formation is composed of red and grey anhydritic claystones and sandstones, and was deposited in a continental lacustrine to mudflat setting (Geluk, 2005). Within the Germanic Basin, the Upper Permian sediments record a catastrophic transgression from the Barents sea (Geluk, 2005; Glennie and Buller, 1983), followed by a regression (progradational) trend (Aigner and Bachmann, 1992).

In the southem part of the Germanic Basin, the shallow marine, evaporitic Zechstein facies are absent and either fluvial or fluvio-lacustrine clastic deposits characterise the Iate Permian record. In northern France (Vosges; Fig. 2), only the uppermost Permian is present and is characterised by fluvial-shallow lake deposits of the "Grès d'Annweiler" and "Grès de Senones" formations (Durand et al., 1994). In the Paris Basin 


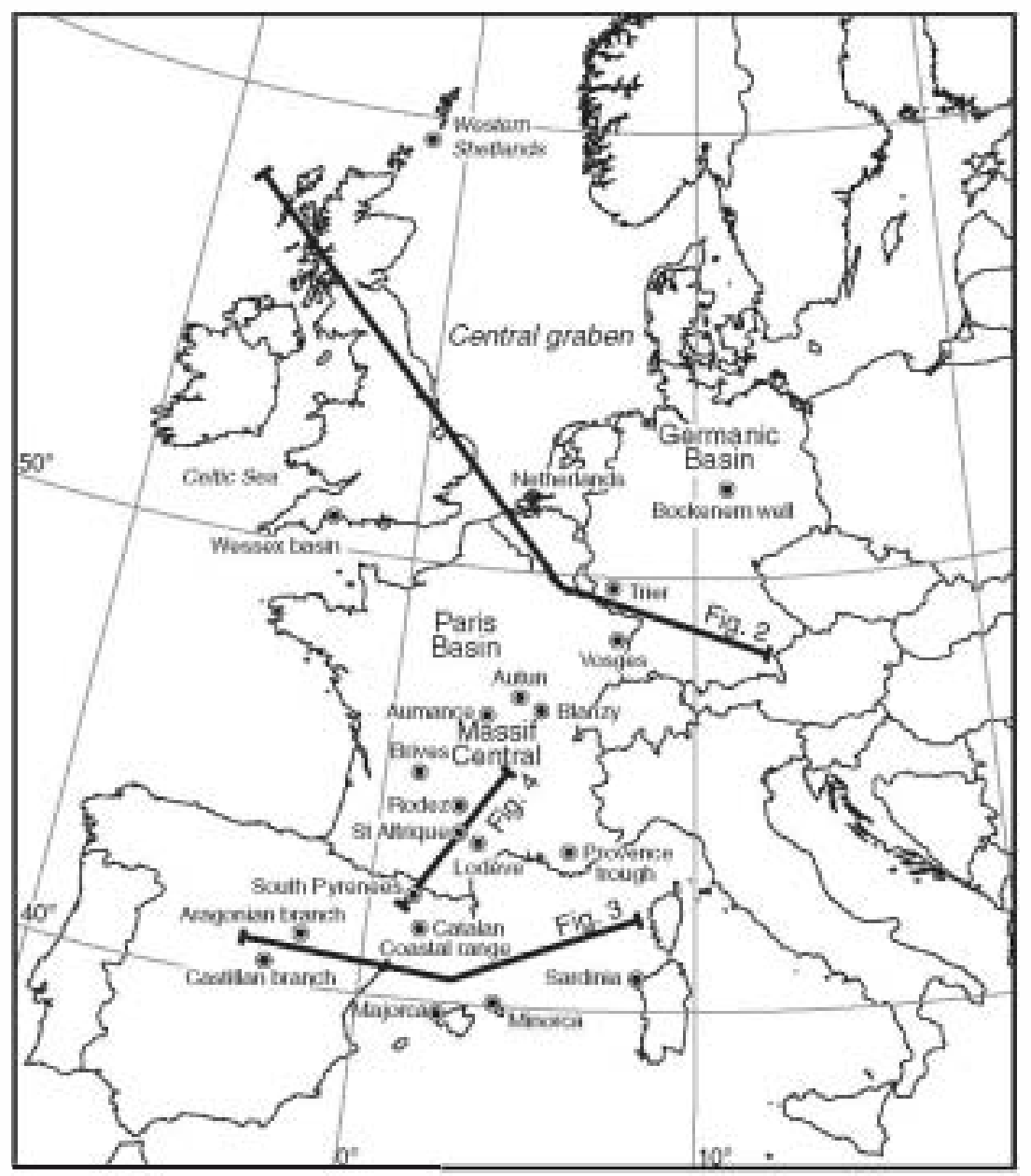

Fig. 1. location of the study areas. Blanzy: Blanzy-l.e-Creusot; Aumance: Bourbon l.'Archambault/Aumance; Provence trough: Bas-Argen, l.uc basin and Toulon-Cuers area.

(Fig. 1), several isolated Permian basins, identified only in the subsurface, are described by Mégnien (1980), Mascle (1990), Perrodon and Zabeck (1990) and Autran et al. (1994); however, the lack of core data does not allow a more precise dating of these Permian deposits.

In the western part of the Zechstein Basin (i.e. the Western Shetlands; Fig. 2), the Midde-Upper Permian is characterised by coastal plain playa-lake deposits (Swiecicki et al., 1995). In southern England (Devon; Fig. 2), the sediments attributed to the MiddleUpper Permian are characterised by continental deposits of the Exeter Group (composed of semi-arid alluvial fans overlain by aeolian deposits) overlain unconformably by fluvial and playa-lake environments of the Aylesbear Group (Edwards et al. 1997; Smith et al., 1992). The Aylesbear Group is considered to be time equivalent to the Zechstein deposits (Late Permian; Hounslow and Ruffell, 2006; Mader and Laming, 1992; Ruffell and Shelton, 2009). In the North Sea Central Graben (Fig. 2), the Middle Permian is characterised by fluvial and aeolian sandstone overlain by marine carbonate and sabkha deposits (Glennie et al., 2003; Goldsmith et al., 1995; Smith et al., 1992).

In the Castillian Branch of the Iberian Ranges (Fig. 3), several palynomorph assemblages found in the Alcotas Formation or the Montesoro Formation, its lateral equivalent, as well as in the lower part of the overlying and unconformable $\mathrm{Hoz}$ del Gallo Formation, indicate a Late Permian ("Thuringian") age (Diéguez and Barron, 2005; Doubinger et al., 1990; López-Gómez et al., 2005; Ramos, 1979). The upper part of the Alcotas Formation would be of early Lopingian age (earlyWuchiapingian; de la Horra, 2008; Diéguezet al., 2007). Therefore, the Boniches and lower Alcotas formations (Fig. 3) could be Guadalupian in age. In the Aragonian Branch of the Iberian Ranges, a Late Permian age is assigned to the Araviana Formation (Arribas, 1984; Bourquin et al., 2007; Diez et al, 2007). In both areas, the palaeocurrent directions point to the SE (Arche and López-Gómez, 1999; López-Gómez et al., 2002; Ramos, 1979; Sopeña and Sánchez-Moya, 2004). In the Catalan Coastal Ranges (Fig. 3), the fluvial conglomerates and sandstones of the Bellmunt and Brugers units (Calvet and Marzo, 1994; Marzo, 1980) are considered to be Late Permian in age by regional comparison with the succession of the Iberian Ranges (Arche et al., 2004). Within the Iberian Peninsula (Fig. 3), the Middle-Upper Permian sediments display an evolution from a retrogradational (from alluvial fan to playa-lake) to progradational pattern (from playa-lake to alluvial fan) in the Castillan Branch (linol et al., 2009). In the Aragonian Branch (Fig. 3), only the retrogradational cycle is observed (Diez et al., 2007).

On the Balearic Islands of Minorca and Majorca (Fig. 3), the sedimentary record follows a similar vertical retrogradational pattern (from alluvial fan conglomerate to playa-lake) and progradational pattern (from playa-lake to sand-sheet rivers) during the MiddleUpper Permian, but the palaeocurrent directions differ (to the SE on Minorca and to the SSW on Majorca; Linol et al., 2009). The MiddleLate Permian on Majorca is represented by fluvial sandstones of the Asa Formation (Fig. 3), which contain a palynoflora of Late Permian age at its top (Ramos and Doubinger, 1989). On Minorca (Fig. 3), the upper part of the fluvial P3 unit displays an increasing number of palaeosols (Gómez-Gras, 1993; Gómez-Gras and Alonso-Zarza, 2003) and the uppermost beds are dated as Late Permian by palynological data (Bercovici et al., 2009; Broutin et al., 1992).

Around the Toulon harbour (Fig. 1) in the Provence Trough (Fig. 3) of southeast France, the Permian formation (the La Motte Formation 


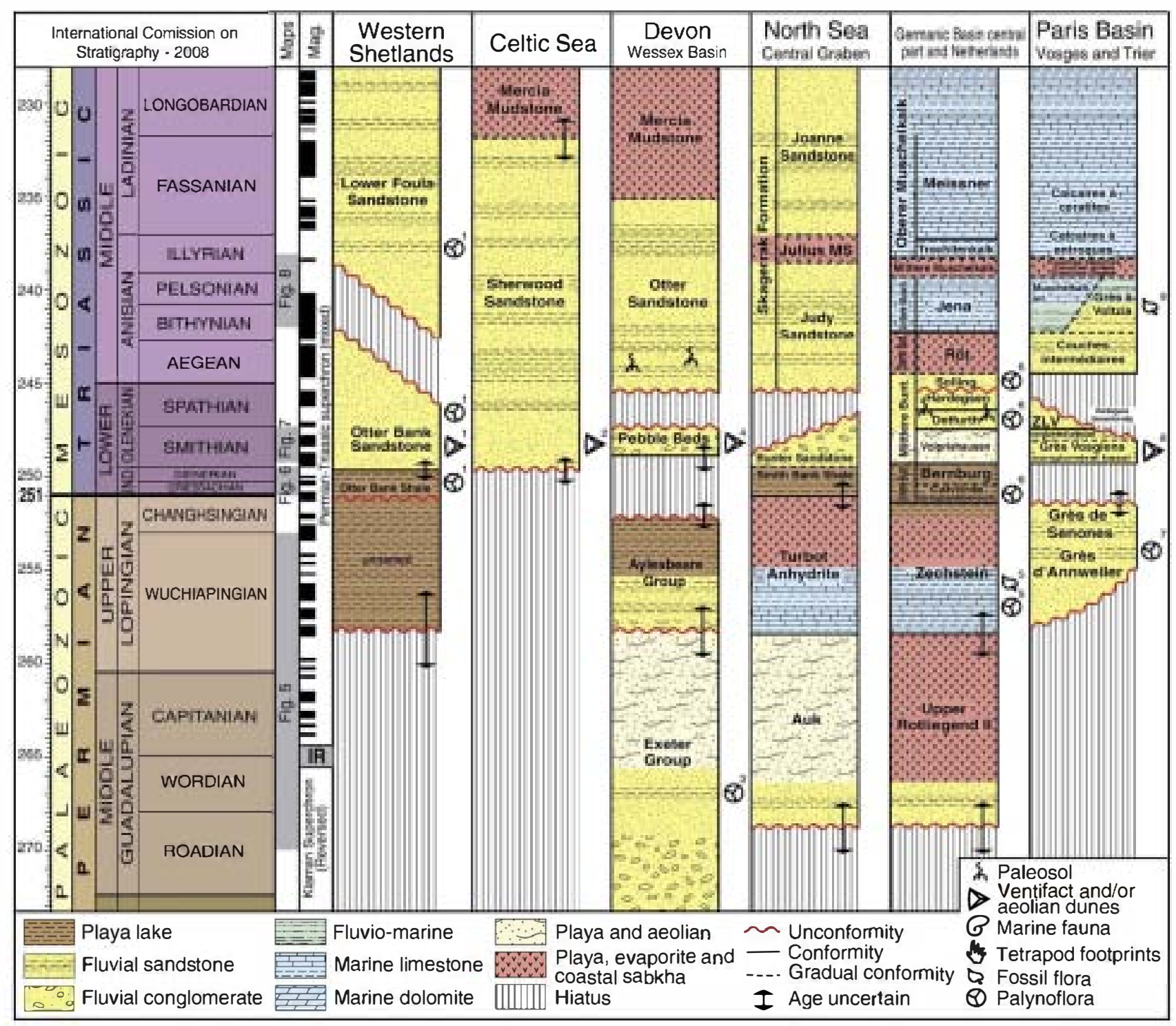

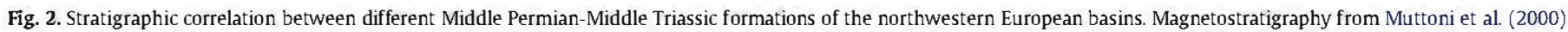

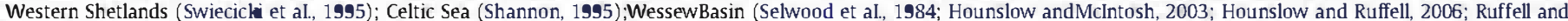

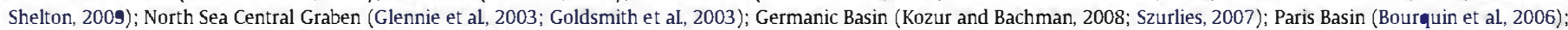

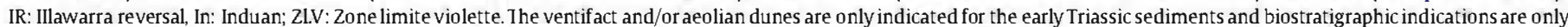

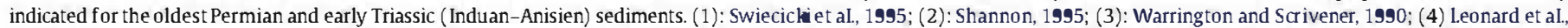

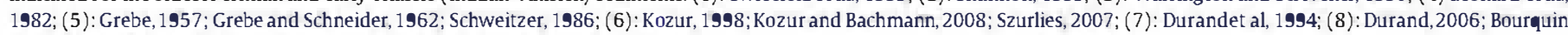
et al, 2006; (9): Durand and Jurain, 1969; Gall, 1971. See Fig. 1 for the locations.

of the Bas-Argen Basin, which is called the Pelitique Formation in the Luc Basin, and the Fabregas-Gonfaron Formation in the Toulon-Cuers area; Durand, 2008; Durand et al., 1989) is made up of playa-lake deposits and has yielded a vertebrate track assemblage of Guadalupian (Wordian) age (Durand, 2008; Gand and Durand, 2006). In northwest Sardinia (Nurra; Fig. 3), a thick Permian-Triassic siliciclastic succession, interpreted as deposited in a playa-lake, crops out over a relatively limited area and shows remarkable similarities with formations in southeast France (around Toulon; Fig. 1). This comparison allows both areas to be considered as parts of the same structural basin, which had two parts that initially faced one another in close proximity (Cassinis et al, 2003). In Nurra, the youngest deposits of the second tectonos atigraphic cycle, i.e. the Cala del Vino Formation (e.g. Cassinis et al, 2003; Ronchi et al., 2008), can be correlated with the Permian Saint-Mandrier Formation (more than $700 \mathrm{~m}$ thick) in the Toulon area (Fig. 3). These deposits are tentatively assigned to the Middle-Upper Permian.
Within the southern Pyrenees (in the Palanca de Noves section; Fig. 4), above the alkaline basalt levels (Bixel, 1987; Bixel and Lucas, 1987), fluvial conglomerates and sandstones of the B1 unit (Gisbert, 1983) are dated as Middle-Late Permian based on a palynomorph assemblage (Broutin et al., 1988).

In the Brive Basin (Fig. 4) within the Massif Central, the MiddleUpper Permian succession shows an evolution from red silty-clay to sandstones to conglomerates in a vertical progradational pattern (Chen et al., 2006). The palaeocurrents point to the east. These sediments, interpreted as fluvial and playa-lake deposits, occur within the Lodève, Rodez and Saint-Affrique basins (Fig. 4; Lopez et al., 2008; Schneider et al., 2006). These three basins may have been connected, with palaeocurrents oriented to the NE in the Saint-Affrique Basin (Châteauneuf and Farjanel, 1989) and to the SE in the Lodève and Rodez basins (Bourges et al., 1987; Châteauneuf and Farjanel, 1989; Rolando et al., 1988). Middle-Upper Permian sediments are not present in the other areas of the Massif Central domain: the Blanzy-Le Creusot, 


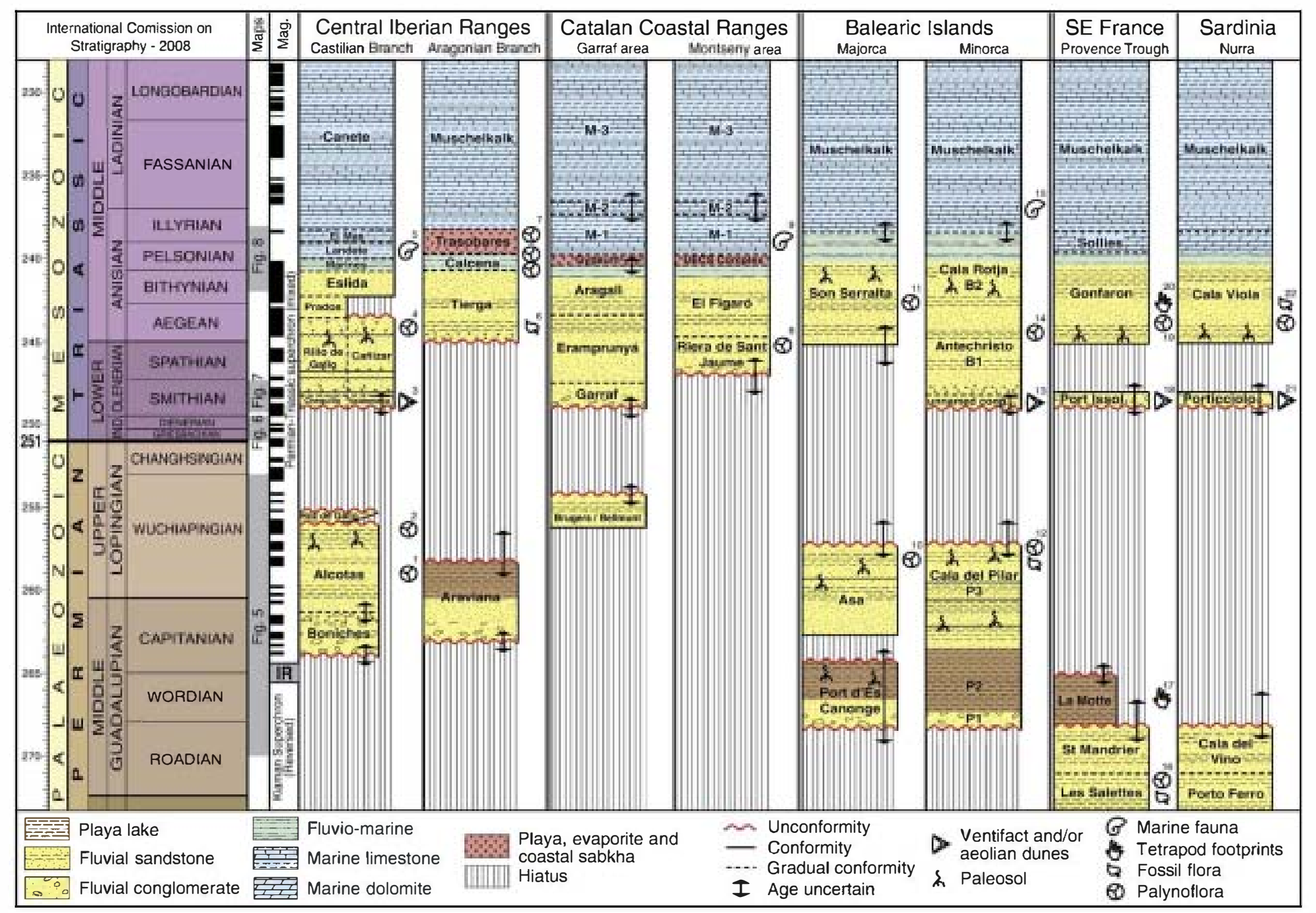

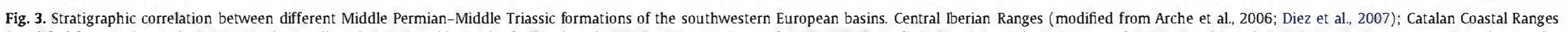

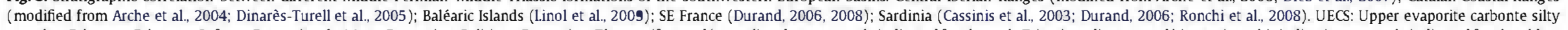

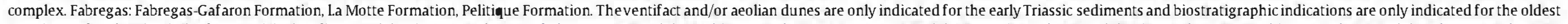

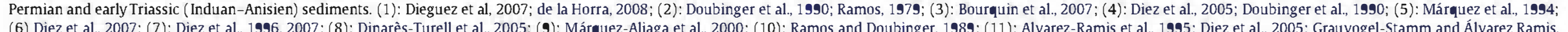

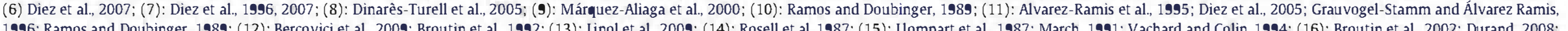

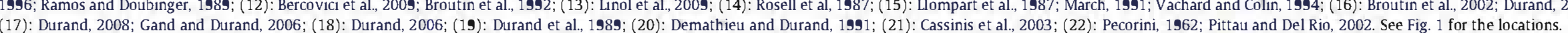




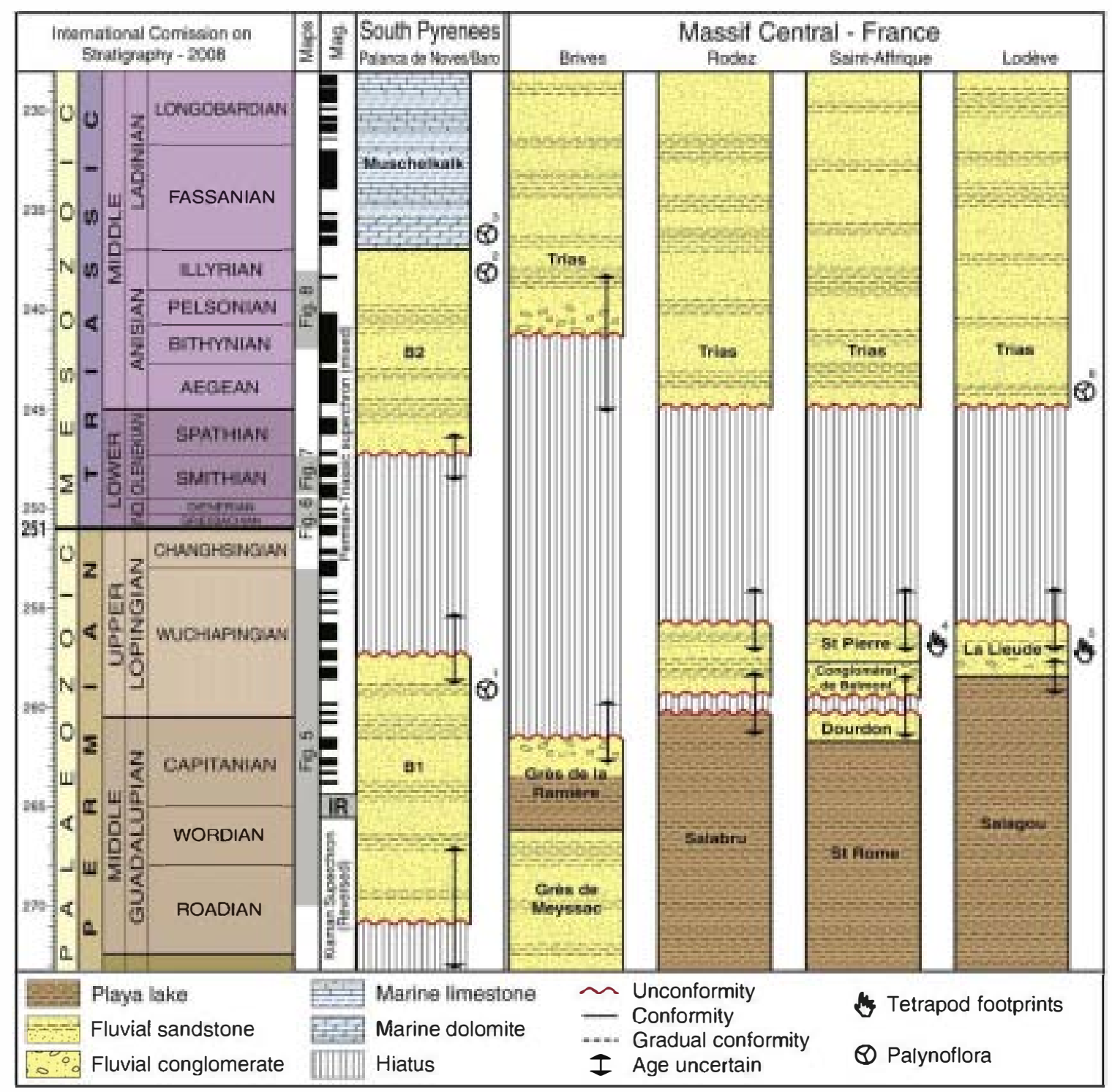

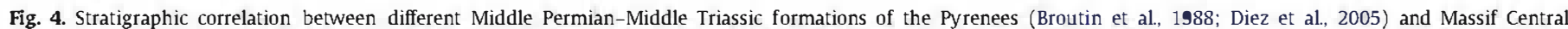

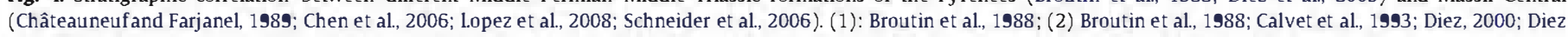
et al., 2005; (3) Calvet et al., 1993, 1994; Diez, 2000; Márquez et al., 1992. (4) and (5): Gand, 1987; (6): Broutin et al., 1992; Diez, 2000; See Fig. 1 for the locations.

Autun and Bourbon-l'Archambault/Aumance basins (Châteauneuf and Farjanel, 1989; Fig. 1).

In summary, in the northern domain (Fig. 2), the Middle-Iate Permian sedimentation is characterised by a transgressive cycle (a vertical evolution from evaporite to shallow marine carbonates) followed by a Late Permian regressive cycle (a vertical evolution from shallow marine to evaporite and to fluvial-lacustrine deposits); the end of the marine Zechstein deposits is still present in the central part of the basin. In the southern domain (Figs. 3, 4), the Middle-Iate Permian is characterised by a retrogradational phase (alluvial fan to playa-lake) followed by either (1) a progradational trend from playalake deposits to fluvial conglomerates and sandstones (Castillan Branch, Catalan Coastal Range, Balearic Islands, Rodez, Saint-Affrique, Lodève) or (2) a period of erosion and/or no deposition during Iate Permian (SE France-Sardinia, Aragonian Branch, Brive, Blanzy-Le Creusot, Autun, Bourbon-l'Archambault/Aumance; Fig. 1). The palaeoflora and sedimentary environments suggest warm and semi-arid climatic conditions (Schneider et al., 2006).

\subsection{The Permian-Triassic Boundary (PTB)}

In the central part of the Germanic Basin (the Netherlands and central Germany; Fig. 2), the transition from Permian to Triassic, seems to be gradual (Szurlies, 2007; Szurlies et al., 2003). The sediments, which were deposited in playa-lake systems, characterise the regressive tendency of the the uppermost Permian, which continues well into the Early Triassic (Aigner and Bachmann, 1992; Aigner et al., 1998). On the margins of the basin, an angular unconformity at the base of the Triassic was caused by deformation and erosion of the uppermost Zechstein cycles, in contrast with the central area, where sedimentation was more or less continuous during this period (Geluk, 1998, 2005; Röhling, 1991; Szurlies, 2007; Szurlies et al., 2003).

A pre-Triassic unconformity is clearly observed on the southwestem edge of the Germanic Basin (the Paris Basin, NE France; Fig. 2), which is associated with a progressive onlap of the Triassic succession on the Palaeozoic basement (Bourquin et al., 2006). An angular unconformity 
separates Permian from Triassic deposits in the western part of the Germanic Basin (Fig. 2): Western Shetlands (Swiecicki et al, 1995), South England (the Wessex Basin; Goldsmith et al., 1995, 2003; Hounslow and McIntosh, 2003), Central Graben (Goldsmith et al., 1995, 2003), and the Celtic Sea (Brookfield, 2008; Shannon, 1995).

Studies on the PTB in Iberia have focused on the Castilian and Aragonian Branches of the Iberian Ranges and on the Catalan Coastal Range (Fig. 3). Within the Aragonian Branch, the lowermost sediments (the Tierga Formation) overlying the Permian-Triassic angular unconformity are dated as Anisian (Diez et al., 2005, 2007). In the Castilian Branch (Fig. 3), an angular unconformity is present within the $\mathrm{Hoz}$ de Gallo Formation: the lower Hoz de Gallo Conglomerates are Late Permian in age (Ramos and Doubinger, 1989) and the upper Hoz de Gallo Conglomerates (or their lateral equivalents: the Chequilla and Valdemeca formations) are considered to be of Early Triassic age (Bourquin et al., 2007; de la Horra et al., 2005; Ramos, 1979). In the Catalan Coastal Ranges, a hiatus is also recorded at the PTB (Fig. 3); in places, the Variscan basement is directly overlain by the Riera de Sant Jaume megasequence (Calvet and Marzo, 1994) dated as upper Olenekian (Spathian) from magnetostratigraphic data (Dinarès-Turell et al., 2005).

In the Balearic Islands of Minorca and Majorca (Fig. 3), an unconformity separates the Upper Permian sediments from either Anisian sandstones (Majorca; Bourrouilh, 1973; Ramos and Doubinger, 1989) or sandstones of undetermined Early Triassic age in other sections (Bourrouilh, 1973; Linol et al., 2009; Rosell and Gómez-Gras, 1990; Rosell et al., 1988). In the Provence Trough (Fig. 3), the lowest Triassic deposits rest unconformably on Permian formations of different ages depending on location (Durand, 2006, 2008). In NW Sardinia, an angular unconformity separates the Triassic deposits from the Cala del Vino Formation, recently asserted to be Middle Permian in age (Cassinis et al., 2003). In the southem Pyrenees and the MassifCentral, an unconformity also occurs between the Upper Permian deposits and the earliest Mesozoic sediments (Fig. 4).

\subsection{The onset of Mesozoic sedimentation}

\subsubsection{Early Triassic: Induan}

At the beginning of the Early Triassic, the sedimentation area was restricted to the northwestern part of the peri-Tethyan domain: in the central part of the Germanic Basin and in the Western Shetlands (Fig. 1).Within the central part of the Germanic Basin (Fig. 2), which was characterised by a playa-lake sedimentary system, the Calvörde and Bernburg formations (Fig. 2) were attributed to the Induan by magnetostratigraphic studies (Szurlies, 2007; Szurlies et al., 2003). These sediments do not have any lateral equivalents on the southwestern margins of the basin and there is a hiatus at the base of the Triassic (Bourquin et al., 2006; Geluk, 1998, 2005).

Induan deposits occur above the Permian-Triassic unconformity in the Western Shetlands (Fig. 2). They constitute coastal alluvial plain deposits of the Otter Bank Shale Formation, dated by palynology (Swiecicki et al., 1995). The palynological assemblages of the Induan deposits indicate a warm and semi-arid environment (Swiecicki et al., 1995). In the Central North Sea Graben, the earliest Triassic sediments are considered as Induan in age (Fig. 2; Goldsmith et al., 1995, 2003; Smith et al., 1992); however, no biostratigraphic data have been published up to now.

\subsubsection{Early Triassic: Olenekian}

In the Germanic Basin (Fig. 2), the Volpriehausen Formation is composed of ephemeral playa-lakes or aeolian deposits (Aigner and Bachmann, 1992; Clemmensen, 1979, 1991; Clemmensen and Tirsgaard 1990; Geluk, 2005; Richter-Bernburg, 1974; Röhling, 1991; Ulicny, 2004; van der Zwan and Spaak, 1992) and is dated as Smithian by magnetostratigraphy (Kozur and Bachmann, 2008; Szurlies, 2007). Using sequence stratigraphic correlations, Bourquin et al. (2006) compared stratigraphic cycles between the Germanic and Paris basins, showing that the coeval deposits of the "Conglomérat basal", "Grès vosgiens" and "Conglomérat principal" formations (Vosges and Trier area; Fig. 2) can be correlated with the Volpriehausen Formation. These formations were laid down under arid climatic conditions by braided rivers, as indicated by the presence of both reworked and in situ aeolian sand dune deposits as well as by wind-worn pebbles, and by the lack of any palaeosol remnants (Bourquin et al, 2009; Durand, 1972, 1978; Durand et al., 1994). Palaeocurrents are generally oriented towards the NNE, thus the river catchment areas were mainly located in the presentday Armorican Massif. The "Conglomérat principal" Formation (Fig. 2) is not thicker than $20 \mathrm{~m}$ at the outcrop in the Vosges area and shows a great lateral continuity towards the east. In Lorraine, the top of the Lower Triassic is marked by a major sedimentary break associated with a period of by-pass and development of the earliest paleosols ("Zone limite violette", noted ZLV in Fig. 2; Gall et al., 1977; Müller, 1954; Ortlam, 1967). This episode could be coeval with the deposition of the Hardegsen and Detfurthformations in the Germanic Basin (Fig. 2), dated as Spathian by magnetostratigraphy (Szurlies, 2007). The Spathian therefore can be characterised by the occurrence of the earliest Mesozoic palaeosols, indicating less arid conditions.

In the westernmost part of the Germanic Basin, i.e. the Devon Basin (Hounslow and McIntosh, 2003), the Central Graben (Goldsmith et al., 1995, 2003), the Celtic Sea (Shannon, 1995), the Western Shetlands (Swiecicki et al., 1995) and the Lower Triassic successions (Fig. 2) are characterised either by ephemeral fluvial deposits or arid alluvial wadi deposits, associated with aeolian dunes and ventifacts. From these sedimentological criteria, these sediments could be Smithian in age. The Spathian, identified in the Western Shetlands (Swiecicki et al., 1995), is difficult to constrain in the other British basins (Fig. 2).

On Minorca Island (Fig. 3), above the pre-Triassic unconformity, sedimentation began with coarse-grained fluvial deposits (unnamed conglomerate in Fig. 2) with palaeocurrents flowing at first towards the SSW and then to the WNW. The absence of fossils in the Lower Triassic of this area prevents any precise dating, but the occurrence of ventifacts together with the lack of palaeosols and clay layers suggest that sedimentation took place in an arid setting (Linol et al., 2009). This arid episode, which marks a climatic change from the underlying Late Permian fluvial sand-sheet environments with palaeosols (P3 in Fig. 2), could be correlated with the early Olenekian arid event (Bourquin et al., 2007; Durand, 2006, 2008; Péron et al., 2005). In this case, Induan deposits should not be preserved in the Triassic succession of Minorca. On Majorca Island, no Lower Triassic sediments have been recognised up to now (Fig. 3).

Lower Triassic deposits (Induan and Olenekian) have not yet been positively recognised in the Iberian Peninsula up to now, except for the upper Olenekian (uppermost Spathian) in the Catalan Coastal Range using magnetostratigraphy (Dinarès-Turell et al., 2005; Riera de Sant Jaume, Fig. 3). Base on stratigraphic location, the Eramprunyá unit of the Garraf area could be time equivalent to the middle part (sandstones) of the Riera de S Jaume megasequence in the Montseny area. In the Central Castillan Branch of the Iberian Range, the beginning of Mesozoic sedimentation is represented by the presence of conglomerates overlain by the thick Cañizar Formation, which is composed of braided sandy fluvial deposits with palaeocurrents flowing towards the SE (López-Gómez and Arche, 1994). These basal conglomeratic units (the upper $\mathrm{Hoz}$ de Gallo, Chequilla and Valdemeca formations, Arche and López-Gómez, 2005; Arche et al., 2004) yield ventifacts (Bourquin et al., 2007). Whereas the basal part of the Cañizar Formation is devoid of any palaeosol, the upper part is characterised first by Mesozoic palaeosols and then by the preservation of an Anisian palynoflora near its top (Diez et al., 2005; Doubinger et al., 1990; López-Gómez et al., 2005). Thus, palaeoclimatic indicators show that the basal part of these sediments could represent at least part of the Smithian (Fig. 3). In the Aragonian Branch of the Iberian Range (Fig. 3), the lowermost sediments above the Permian are dated 
as Anisian (Diez et al., 2007) and the whole of the Early Triassic is lacking in this area.

Above the PTB in NW Sardinia, (the Cala Viola area, Nurra; Fig. 3), the "Conglomerato del Porticciolo" Formation (Cassinis et al., 2003) is mainly composed of well-rounded vein-quartz pebbles and cobbles, deposited by braided rivers flowing to the east. Cassinis et al. (2003) observed slightly reworked and even in situ ventifacts in this formation, as well as some aeolian sandstone dune remnants. Together with the entire stratigraphic framework, these observations are used as an argument for the correlation of this formation with the "Poudingue de Port-Issol" Formation in the Provence Trough, which also contains ventifacts. In the western part of the Provence Trough (Fig. 3), the main palaeocurrents of the fluvial Triassic sediments are towards the SW, opposite to those observed in the Permian (Durand, 1993; Durand et al., 1989). In comparison with North European basins, these conglomerates are more likely of Smithian age and Induan sediments would not be preserved in this area (Fig. 3).

In the southern Pyrenees (Fig. 4), Lower Triassic sediments have not yet been recognised. The fluvial Mesozoic sedimentation started with either an oligomictic conglomerate or red silty clay beds, dated as Anisian at their top (Broutin et al., 1988; Calvet et al., 1993; Diez, 2000; Diez et al., 2005). Thus, the lower part of this fluvial unit (B2, Fig. 4) could be of Early Triassic age, probably Spathian or even late Smithian (some ventifacts were found in the oligomictic basal conglomerate of the Basque Country, western Pyrenees).

\subsubsection{The Hardegsen unconformity and the Olenekian-Anisian transition}

In the Germanic Basin, the base of the Solling Formation corresponds to the erosional Hardegsen unconformity (Fig. 2), formed during an intra-Spathian time span (Geluk and Röhling, 1997; Szurlies, 2004, 2007), when approximately $100 \mathrm{~m}$ of Middle Buntsandstein deposits could have been locally eroded (Aigner and Bachmann, 1992). This unconformity is related to one of the most pronounced extensional tectonic events observed in the German Triassic (Röhling, 1991; Trusheim, 1961, 1963; Wolburg, 1968). The Solling Formation, interpreted as fluvial deposits (Aigner and Bachmann, 1992) preserved in the Germanic Basin, are dated as upper Olenekian (Kozur, 1998; Szurlies, 2007) and could be equivalent to an episode of sediment by-pass at the basin margins. Moreover, Geluk (1998) showed that the base of the Solling Formation becomes progressively younger to the west, the formation thinning away in the same direction. In the southern part of the Germanic Basin (NE France, Fig. 2), the "Conglomérat principal" Formation rarely crops out north of the Vosges Massif (near the German boundary) because it is truncated there by the Hardegsen unconformity (Fig. 2), which even cuts locally into the "Grès vosgien" Formation (Bourquin et al., 2006).

An unconformity between the Lower Triassic and Anisian deposits is also present in several areas: the Central Graben Basin (Goldsmith et al., 1995, 2003; Smith et al., 1992), the Wessex Basin (Hounslow and McIntosh, 2003) and the Western Shetlands (Swiecicki et al., 1995). This might indicate erosion of the upper Olenekian in this area (Fig. 2).

A hiatus, marked by palaeosol development, occurs in the Provence Trough (Durand, 2008; Durand et al, 1989) and Sardinia (Cassinis et al., 2003, 2007; Fig. 3). However, no indication of the Hardegsen unconformity is observed in the other SW European basins (Figs. 2, 3).

\subsubsection{Middle Triassic: Anisian and Ladinian}

In the Germanic Basin (Fig. 2), the Olenekian-Anisian transition is located in the uppermost beds of the playa-lake Solling Formation (Kozur and Bachmann, 2008). Therefore, the main part of the overlying unit, the Röt Formation, is Middle Triassic (Aegean, earliest Anisian in age, Kozur and Bachmann, 2008; Szurlies, 2007). This formation consists of evaporitic shallow marine and sabkha deposits
(Aigner and Bachmann, 1992; Geluk, 2005); it represents the first Triassic occurrence of halite deposition in the Germanic Basin.

The lateral equivalents of the Röt Formation in the southern part of the Germanic Basin (NE France; Bourquin et al., 2006; Fig. 2) are the fluvial sediments composing the "Couches intermédiaires", which show an enhanced development of floodplains with associated dolocretes derived from hydromorphic palaeosols (Durand, 1978; Durand and Meyer, 1982). There, the only biochronologic evidence is provided by the "Grès à Voltzia" Formation, where macrofauna and palynoflora indicate an early-middle Anisian age (Durand and Jurain, 1969; Gall, 1971). The fluvial “Grès à Voltzia” evolves eastwards (and upwards) into deposits with increasing marine influence (Bourquin et al., 2006) and then passes laterally into marine limestones characterising the Lower Muschelkalk (the Jena Formation in Germany; Fig. 2). In NE France, fluvial systems appear to collapse suddenly at the beginning of the evaporitic episode corresponding to the Middle Muschelkak (the "Couches rouges", "Couches grises" and "Couches blanches"), which precedes the extensive deposition of marine carbonates during the Illyrian-Fassanian (Fig. 2). The vertical passage from the "Couches intermédiaires" to the Anisian-Ladinian marine limestones (Duringer and Hagdorn, 1987) characterises a general transgressive trend.

As for the westernmost part of the Germanic Basin (Fig. 2), the Anisian is characterised by either fluvial systems in the Devon Basin (Hounslow and McIntosh, 2003), Central Graben (Goldsmith et al., 1995, 2003) and Westem Shetlands (Swiecicki et al., 1995), or by distal floodplain or inland sabkha deposits in the Celtic Sea (Shannon, 1995). The Ladinian depositional environments are similar to those of the Anisian, except in the Devon Basin (Hounslow and McIntosh, 2003) and the Celtic Sea (Shannon, 1995), where the fluvial deposits evolve vertically to coastal sabkha deposits (Warrington and Ivimey-Cook, 1992).

In the Aragonian Branch of the Iberian Ranges (Fig. 3), a palynological analysis of fluvial-coastal deposits of the Tierga, Cálcena and Trasobares formations allowed dating of these deposits as lowermiddle Anisian for the Cálcena Formation and middle-upper Anisian for the Trasobares Formation (Diez et al., 1996, 2007). In the Castilian Branch (Fig. 3), the ammonite and foraminifera assemblages yield a late Anisian age for the basal limestones of the Landete Formation (Arche and López-Gómez, 1999; Arche et al., 2004; López-Gómez et al., 1998, 2002; Márquez et al., 1994). In the Catalan Coastal Range, the top of Riera de Sant Jaume is dated as Aegean by magnetostratigraphy and palynology (Dinarès-Turell et al., 2005) and the conodonts yield a late Anisian age for the lower Muschelkalk facies (named M-1, Fig. 3, middle Pelsonian-upper Illyrian; Dinarès-Turell et al, 2005; Márquez-Aliaga et al., 2000). Hence, a connection with the open Tethys Ocean was established during the Anisian.

On Minorca (Fig. 3), the Anisian s.l. is well marked by a transition from braided river deposits, with in situ and reworked palaeosols (dolomite breccias), to fluvial-coastal and shallow marine deposits (Muschelkalk, Fig. 3) and are dated as upper Anisian-Ladinian (Llompart et al., 1987; March, 1991; Vachard and Colin, 1994). The palaeocurrents are directed towards the SE, which implies a continental environment located to the west and open sea to the east. On Majorca, the siliciclastic Son Serralta Formation (Fig. 3) becomes more argillaceous towards its top and contains palaeofauna (Calafat, 1988) and palaeoflora (Grauvogel-Stamm and Álvarez Ramis, 1996) associations of middle Anisian age. These sandstones were deposited in a distal braidplain environment evolving into coastal shallow deltaic or beach-prograding complexes (López-Gómez et al., 2002).

In the Provence Trough and in Sardinia (Fig. 3), the basal contact of the "Grès de Gonfaron" and "Arenarie di Cala Viola" formations is very sharp and marked by the sudden appearance of caliche nodules, mainly reworked and sometimes in situ. In the distal part of the Provence Trough (Toulon), as well in Sardinia, the fluvial sandstones 
grade upwards into terminal fan and playa deposits. Other than the caliche horizons, there is relatively frequent evidence of biological activity: e.g. vegetation-induced primary sedimentary structures (Rygel et al., 2004) and trace fossils that are mainly invertebrate burrows (e.g. Scoyenia, Beaconites, Phycodes, Arenicoloides, etc). Nevertheless, the only remains of biochronologic significance in the "Grès de Gonfaron" are palynomorphs found in the uppermost part, which are of an early Anisian age (Adloff, in Durand et al., 1989). Occasional occurrences of tetrapod footprints have also been recorded. Although the latter provide less precise dating than palynomorphs, their stratigraphic ranges agree well with an early Anisian age for these sediments (Demathieu and Durand, 1991). In NW Sardinia, reddish siliciclastic deposits from the subsurface (the Cugiareddu well), correlating to the "Arenarie di Cala Viola", yielded two distinct palynomorph assemblages that are ascribed to an Olenekian?-early Anisian and late Anisian age, respectively (Pittau and Del Rio, 2002). In the Provence Trough and in Sardinia (Fig. 3), these fluvial mature siliciclastics pass upwards into floodplain-playa and subsequently to Anisian age pre-evaporitic marly-dolomitic deposits. They are overlain by marine Middle Triassic carbonates of the Muschelkalk (Brocard and Philip, 1989; Carrillat et al., 1999; Posenato et al., 2002; Ronchi, 2004).

In the southern Pyrenees (Fig. 4), above the Anisian siliciclastic sediments, a dolomitic unit representing the Muschelkalk facies has been dated as Ladinian (Calvet et al., 1993, 1994; Diez, 2000; Márquez et al., 1992). The earliest Triassic sediments deposited on the French Massif Central (Figs. 4, 1) are dated as Anisian in the Lodève Basin (Broutin et al., 1992; Diez, 2000). They are considered as Anisien in the Rodez and Saint-Affrique basins by comparison with the Lodève Basin (Châteauneuf and Farjanel, 1989), and as Iadinian in the BlanzyLe Creusot and Autun basins (Courel et al., 1984). In other areas, the Early and Middle Triassic correspond to a hiatus and the earliest Mesozoic sediments are of Carnian-Hettangian age (Blanzy-Le Creusot, Autun, Bourbon-l'Archambault/Aumance; Fig. 1).

\subsubsection{Conclusion}

In summary, within the northwestern Tethys domain, the Early Triassic (Induan), which is preserved only in the Germanic basin and Western Shetlands (Figs. 1, 2), corresponds to playa-lake deposits in warm and semi-arid climate conditions. It represents the end of the Permian progradational trend, i.e. the regressive tendency that started in the uppermost Zechstein (Aigner and Bachmann, 1992; Aigner et al., 1998; Röhling, 1991; Szurlies et al., 2003). In other basins, the onset of Mesozoic sedimentation, above the Permian-Triassic unconformity, is dated as Olenekian. The Olenekian began with warm and hyper arid climate conditions of the Smithian (no palaeosols, the presence of ventifacts, and aeolian deposits). This was followed by more humid conditions, with the development of the earliest Mesozoic palaeosols, considered as Spathian. The ages are obtained through a comparison with magnetostratigraphic data for the Germanic Basin (Szurlies, 2007). Within the northern domain, above a sedimentation hiatus marked along the margin of the basins by palaeosol development, an intra-Spathian tectonically induced unconformity (Hardegesen unconformity) is observed (Fig. 2). In the southern domain, only a sedimentation haitus, marked by palaeosol development, occurs (Fig. 3). Above this hiatus or unconformity, the Anisian-Ladinian deposits evolve vertically from fluvial to open marine sedimentation, except in some of the Massif Central basins (Fig. 1) where a sedimentation gap occurs from the pre-Triassic unconformity to the Carnian or Hettangian (Figs. 3, 4). Throughout the Spathian and Anisian, the presence of palaeosols and the development of palyno- and macrofloras attest to less arid conditions over the study area. Thus, the lack of typical Early Triassic continental fossils can be explained not only by a slow recovery after the Permian-Triassic biologic crisis (López-Gómez et al., 2005), but also by a true stratigraphic gap including part of the Early Triassic (Induan) and/or by climatic conditions that were not suitable for the development of most of the flora and fauna during the Lower Olenekian (i.e. "desert" environments).

\subsection{Palaeogeographical implications}

This review of the Middle Permian-Middle Triassic record of several western European basins (Figs. 2-4) forms the basis of a discussion of the palaeogeographic evolution of these basins. In the Laurasia supercontinent, the palaeogeography and mountain chain morphology are reconstructed from: (1) previously published maps of the kinematic reconsuction of plate motions during the Middle/ Late-Permian, Early and Middle Triassic periods (Dercourt et al., 1993, 2000; Ziegler, 1982, 1990; Ziegler et al., 1997); and (2) original sedimentological data, such as palaeocurrent directions, boundaries for the marine influence, and areas of erosion and/or no deposition (palaeorelief). The mean Upper Permian Appalachian-Variscan Belt altitude is estimated to be around $2000 \mathrm{~m}$, as deduced from numerical modelling on mountain elevation by Fluteau et al. (2001). The palaeolatitude reconstructions, based on Ziegler's reconstructions

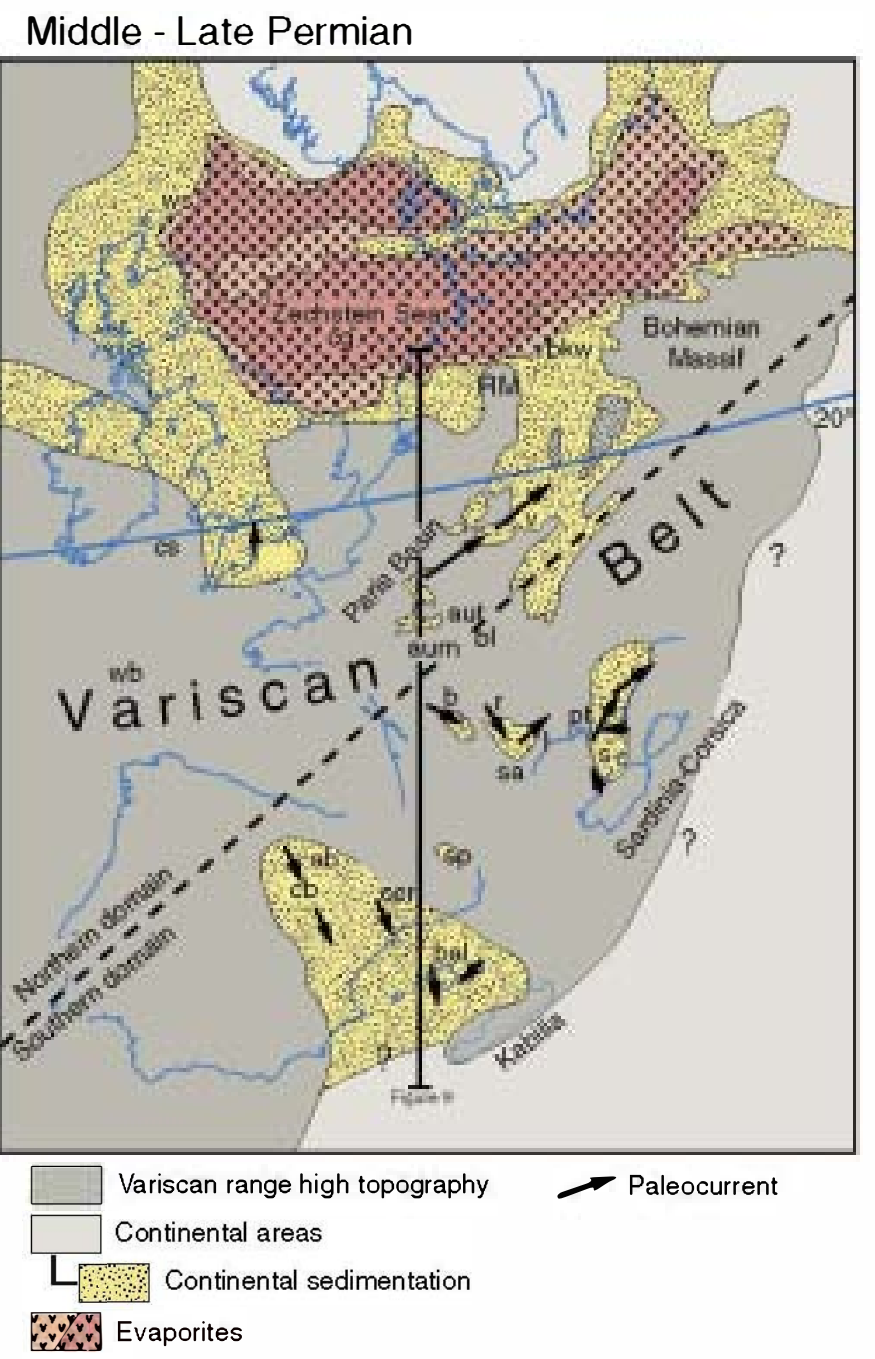

Fig. 5. Middle-l.ate Permian palaeogeographical reconstruction of the northwestern peri-Tethyan domain. Ws: Western Shetlands; cs: Celtic Sea; wb: Wessex Basin; cg: North Sea Central Graben; bkw: bockenem well; v: Vosges and Trier area; cb: Castillan Branch; ab: Aragonian Branch; ccr: Catalan Coastal Range; bal: Balearic Islands (Minorca and Majorca); pt: Provence through (Bas-Argen, luc basin and Toulon-Cuers area); s: Sardinia; sp: southern Pyrenees; b: Brive; r: Rodez; sa: Saint Affrique; I: lodève; aut: Autun; aum: Bourbon l.Archambault/Aumance; bl: Blanzy-Le Creusot; RM: Rhenish Massif. Palaeolatitudes are from Ziegler et al. (1997). 
(1990), show that the northwestern continental Tethyan domain is above the equator during the Middle-Late Permian and migrated northward until the middle Ladinian.

At the scale of the western European peri-Tethyan basins, in the northern domain (Fig. 5), the Middle-Late Permian sedimentation areas are either isolated or connected to a large sub-endorheic basin. This basin, occupied by the Zechstein Sea, is characterised by the vertical evolution from evaporite to shallow marine carbonates to playa-lake and fluvial deposits. Fluvial-lacustrine deposits occur on the southern margin of this large basin, with a vertical evolution towards increasingly dominant fluvial deposits. The palaeocurrent directions point to the north. Within the Paris Basin, sedimentation took place in isolated subbasins during this period. In the southem domain (Fig. 5), the Middle-Iate Permian sedimentation took place in numerous endorheic basins with palaeocurrent directions indicating local sediment sources (Fig. 5). Three types of sedimentary basins can be distinguished (Fig. 5): (1) a large southwest basin (the Iberian Range and Balearic area) with fluvial networks flowing mainly towards the south-southeast but probably not connected to the Tethys Ocean; (2) numerous small basins with active sedimentation and palaeocurrent directions indicating local sources (e.g. the Pyrenees, Brive, Rodez, Saint-Affrique, Lodève, Nurra, SE France basins); and (3) areas under erosion and/or with no deposition during the Iate Permian (e.g. Blanzy-Le Creusot, Autun, Bourbon-l'Archambault/Aumance, Sardinia and Provence). These large endorheic domains were limited at the southeastern border (Fig. 5) by Corsica-Sardinia palaeorelief (since the Early Permian; Cassinis et al., 2003; Ronchi et al, 1998, 2008) and probably also by the relief corresponding to the future Kabylia microplate (Edel et al., 2001). The climate in these domains, as well as in the northern domain, was warm and semi-arid (Schneider et al., 2006).

At the scale of the study area, a major erosional boundary surface can be followed almost everywhere between Permian and Triassic deposits, except in the northem domain (the Central Germanic Basin and the Western Shetlands; Figs. 2-4). This boundary surface may correspond to an erosional and, in places, an angular unconformity. The earliest Triassic sediments (Induan) are preserved only in the central part of the Germanic Basin (the North Sea Central Grabben and Western Shetlands; Fig. 2). All the intra-belt domains were under erosion at that time (Figs. 3, 4); all the sediment supply by-passed the continental area and was preserved in the extra-belt domains (Fig. 6). The Induan sediments are mainly attributed to playa-lake systems evolving under warm and semi-arid climatic conditions, similar to those characterising the end of the Permian, and they reflect the regressive tendency that started in the uppermost Zechstein (Aigner and Bachmann, 1992; Aigner et al., 1998; Röhling, 1991; Szurlies et al., 2003).

The deposits overlying the Permian-Triassic unconformity are characterised by marked changes in sedimentological features. Moreover, in some basins, a change in the palaeocurrent directions is observed across the unconformity (NW Sardinia, SE France, Minorca, Figs. 5, 7). The fluvial siliciclastics lack palaeosol remnants, but include ventifacts and aeolian dune deposits. Like the Volpriehausen Formation of the Germanic Basin, they were laid down during an arid episode dated as lower Olenekian (Smithian) by magnetos ratigraphy (Szurlies, 2007). The first occurrence of Mesozoic palaeosols, which are considered as Spathian in age, indicated that more humid conditions prevailed later on when compared to their equivalents in the Germanic Basin.

In the Laurasia supercontinent, three domains can be distinguished based on our study of the Early Triassic: a northern domain separated from a southern domain by an intra-belt domain (the AppalachianVariscan Belt). In the northern and southem domains, Mesozoic sedimentation mainly began in the early Olenekian (Smithian), with fluvial systems flowing through the arid plains towards the north and the south, respectively. Erosion occurred in the sectors pertaining to the Appalachian-Variscan Belt, where no Lower Triassic sediment preservation is recorded (Fig. 7).

\section{Induan}

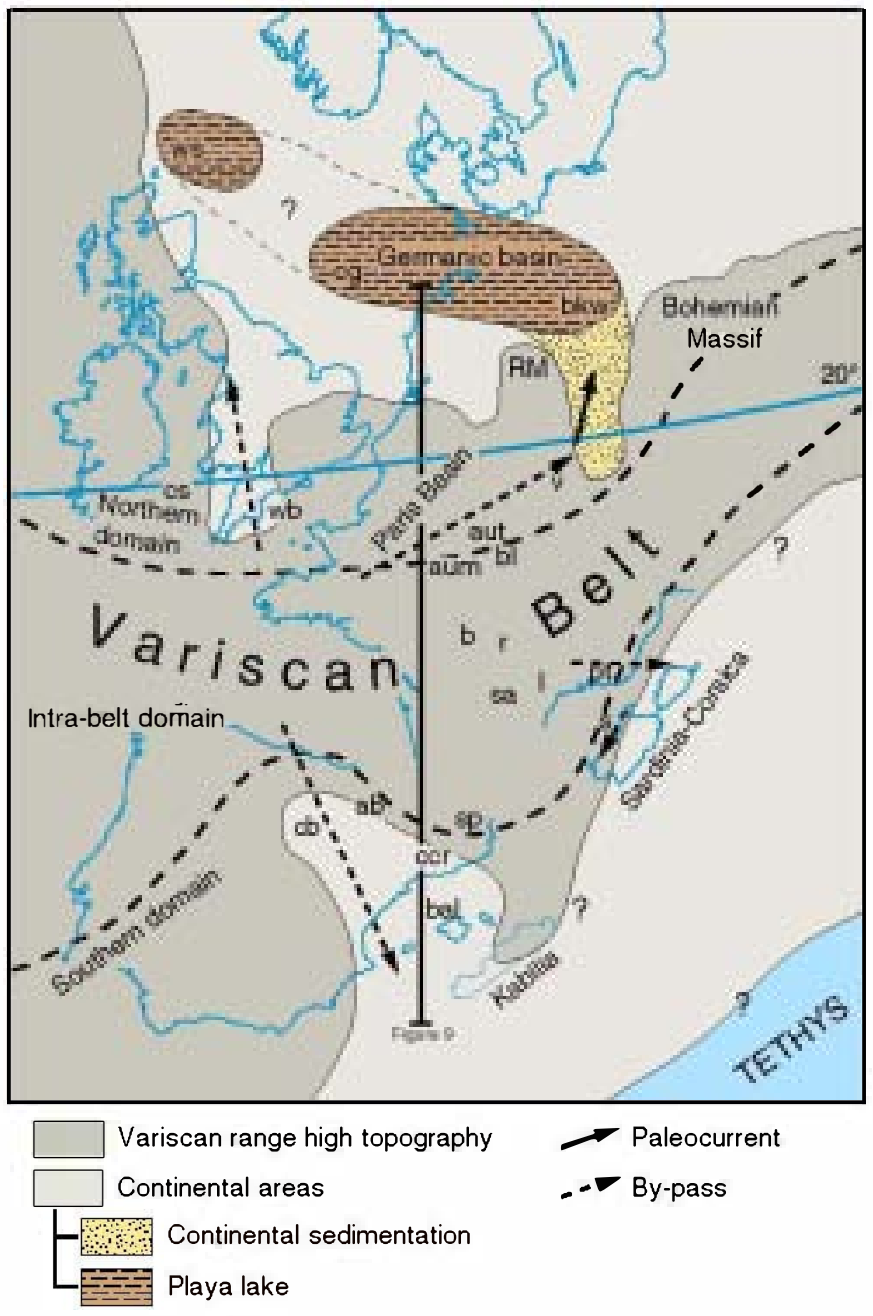

Fig. 6. Induan palaeogeographical reconstruction of the northwestern peri-Tethyan domain. Ws: Western Shetlands; cs: Celtic Sea; wb: Wessex Basin; cg: North Sea Central Graben; bkw: bockenem well; bkw: bockenem well (central Germanic Basin); v: Vosges and Trier area; cb: Castillan Branch; ab: Aragonian Branch; ccr: Catalan Coastal Range; bal: Balearic Islands (Minorca and Majorca); pt: Provence through (BasArgen, luc basin and Toulon-Cuers area); s: Sardinia; sp: southern Pyrenees; b: Brive; r: Rodez; sa: Saint Affrique; I: Iodève; aut: Autun; aum: Bourbon l.Archambault/ Aumance; bl: Blanzy-Ie Creusot; RM: Rhenish Massif. Palaeolatitudes are from Ziegler et al. (1997).

Another tectonically induced, major sedimentary break, the Hardegsen unconformity, can be observed within the upper Spathian, especially in northern European basins (Fig. 2). Above the Lower Triassic, braided fluvial deposits yielded both macro- and palynofloras, allowing the first palaeontological dating of Mesozoic sediments as Anisian. The Anisian-Ladinian is characterised by a vertical transition from fluvial to open marine sedimentation, taking place during the Muschelkalk Sea transgression (Fig. 8). A hiatus encompassing the Early and Middle Triassic occurred in the basins located within the Appalachian-Variscan Belt (those of the Massif Central): Brive, Blanzy-Le Creusot, Autun and Bourbon-l'Archambault/ Aumance basins (Fig. 1). The earliest Mesozoic sediments here are Carnian-Hettangian in age.

\subsection{Discussion}

After this review of the Middle Permian-Middle Triassic record of several European basins (Figs. 2-4) and the palaeogeographic reconstruction of the sedimentary basins (Figs. 5-8), the impact of 


\section{Olenekian}

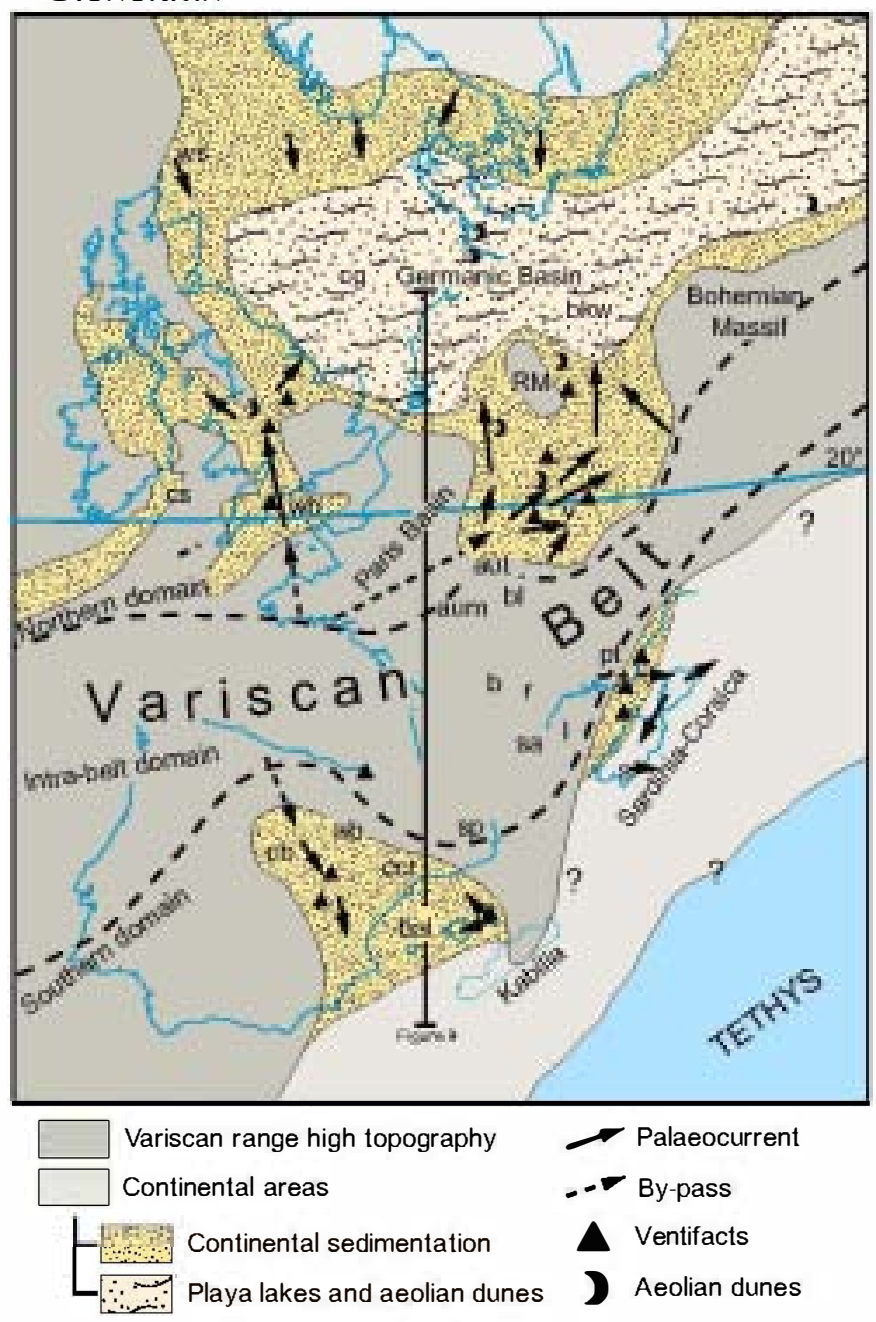

Fig. 7. Early Olenekian (Smithian) palaeogeographicalreconstruction of the northwestern peri-Tethyan domain Ws: Western Shetlands; cs: Celtic Sea; wb: Wessex Basin; cg: North Sea Central Graben; bkw: bockenem well; bkw: bockenem well (œntral Germanic Basin); v: Vosges and Trier area; cb: Castillan Branch; ab: Aragonian Branch; ccr: Catalan Coastal Range; bal: Balearic Islands (Minorca and Majorca); pt: Provence through (Bas-Argen, l.uc basin and Toulon-Cuers area); s: Sardinia; sp: southern Pyrenees; b: Brive; r: Rodez; sa: Saint Affrique; 1: Iodève; aut: Autun; aum: Bourbon l.'Archambault/Aumance; bl: Blanzy-Ie Creusot; RM: Rhenish Massif.. Palaeolatitudes are from Dercourt et al. (2000)

tectonics, climate and sediment supply on the sediment preservation can be discussed.

\subsubsection{Climate}

Throughout the northern hemisphere and as far as the South China Block (Yu, 2008), where continuity can be documented between the Permian and Triassic sedimentary records, the climate seems to have evolved from semi-arid towards more humid conditions beginning in the Changhsingian-Griesbachian Stages (e.g. Fuglewicz, 1980; Kozur, 2003). Macrofloras show a predominantly Permian character, whereas the palynoflora indicate transitional Permian-Triassic characteristics (Lozovsky et al., 2001; Ouyang and Norris, 1999). A clear climate change from semi-arid to hyper-arid conditions occurs only during the early Olenekian (Smithian). At the end of the Olenekian (Spathian) and during the Anisian, palaeosols, palyno- and macrofloras again indicate less arid conditions at the scale of the study area. The Early Triassic arid episode could have been triggered by a global-scale phenomenon, as suggested by recent studies on ammonoids (Brayard et al., 2006), where climate changes are observed during the Smithian.

\section{Middle Anisian}

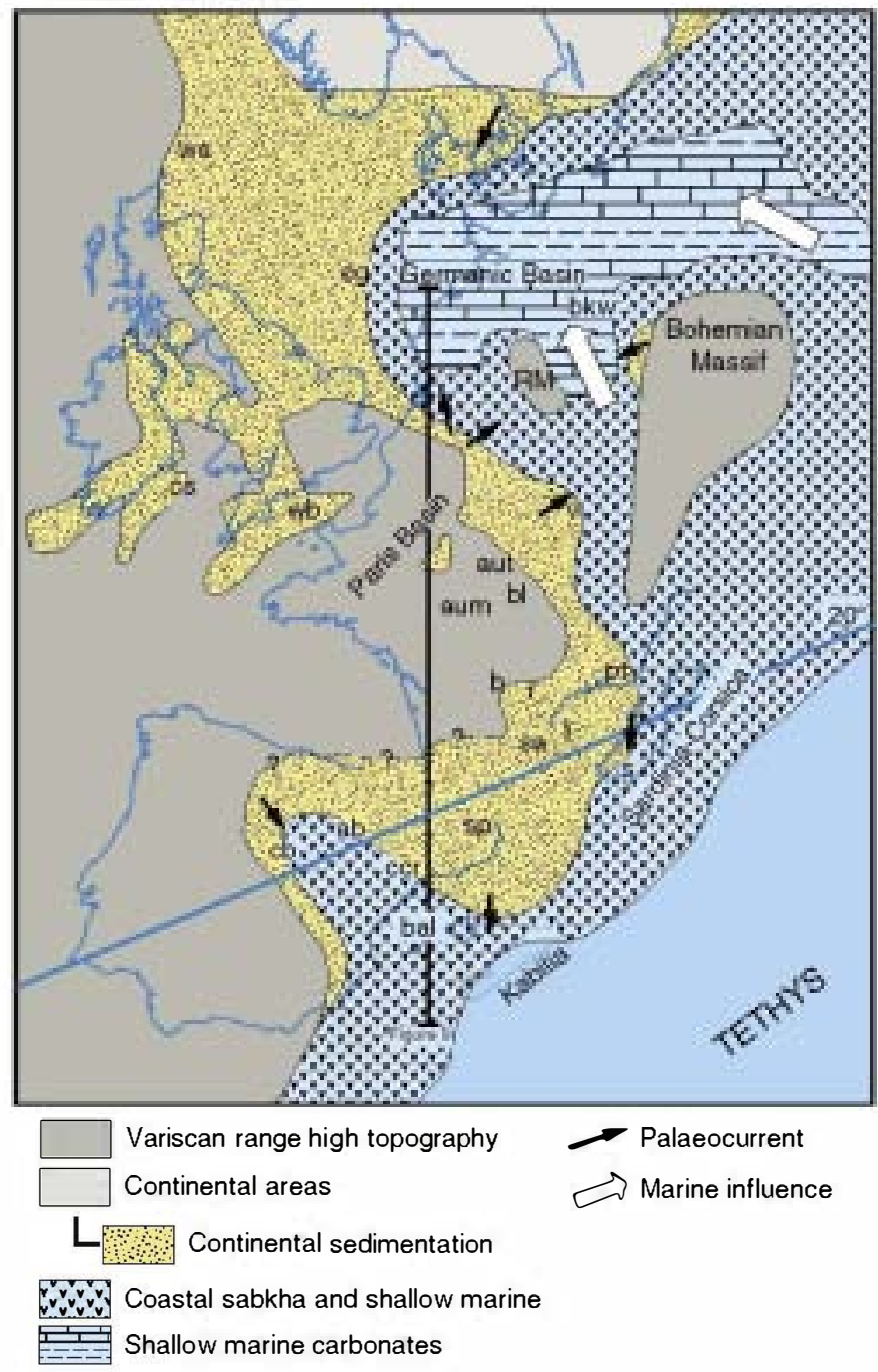

Fig. 8. Middle Anisian palaeogeographical reconstruction of the northwestern periTethyan domain. Ws: Western Shetlands; cs: Celtic Sea; wb: Wessex Basin; cg: North Sea Central Graben; bkw: bockenem well (central Germanic Basin); v: Vosges and Trier area; cb: Castillan Branch; ab: Aragonian Branch; ccr: Catalan Coastal Range; bal: Balearic Islands (Minorca and Majorca); pt: Provence through ** (Bas-Argen, l.ucbasin and ToulonCuers area); s: Sardinia; sp: southern Pyrenees; b: Brive; r: Rodez; sa: Saint Affrique; I: l.odève; aut: Autun; aum: Bourbon l.'Archambault/Aumance; bl: Blanzy-Le Creusot; RM: Rhenish Massif. Palaeolatitudes are from Dercourt et al. (1993).

Furthermore, it should be noted that even in South Africa, recent research has provided evidence of a vegetated landscape during the beginning of the Triassic and, conversely, of an aphytic interval between the deposits dated as Early and Middle Triassic (Gastaldo et al, 2005). Therefore, there is no evidence for a climate change during the Palaeozoic and Mesozoic transition. The climate always reflects warm and semi-arid conditions. A drastic change occurs at the InduanOlenekian boundary and the hyper arid episode of the westem Tethys domain appears to last throughout the Smithian (Fig. 9).

\subsubsection{Sediment supply}

In the northern and southem borders of the Variscan Belt (Figs. 5, 9A), the Late Permian is characterised by a general vertical progradational wend from evaporite sabkha, playa-lake or floodplain sediments to fluvial deposits (Figs. 2-4). The similar evolution observed in these two domains leads to the conclusion that this trend was controlled by allocyclic factors independent of the basin location, such as intraplate tectonics or climate change. It could be explained by either an increase in sediment supply 
A. MIDDLE - LATE PERMIAN

Climate: Warm and semi-arid Paleosols

Fluvial and playa-lake, evaporites in Zechstein Sea

B. INDUAN

Climate: Warm and semi-arid Paleosols

Sedimentary by-pass and erosion, playa lake in Germanic Basin

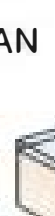

C. EARLY OLENEKIAN (SMITHIAN)

Climate: Warm and hyper-arid No paleosol

Fluvial and aeolian

Ventifacts

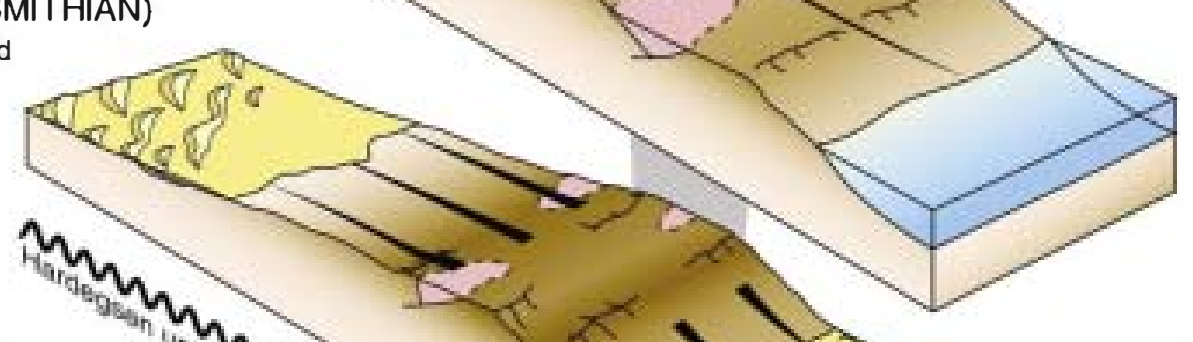

D. MIDDLE ANISIAN

Climate: Warm and semi-ard Paleosos

Fluvio-marine and marine

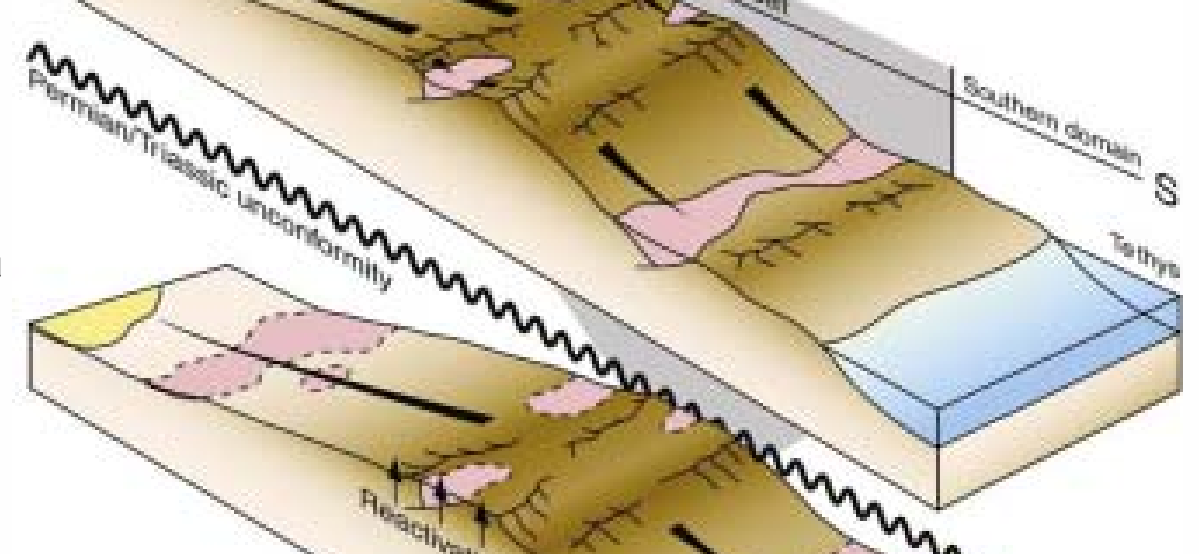

\section{E. LADINIAN}

Climate: Warm and semi-arid Paleosols Fluvio-marine and marine
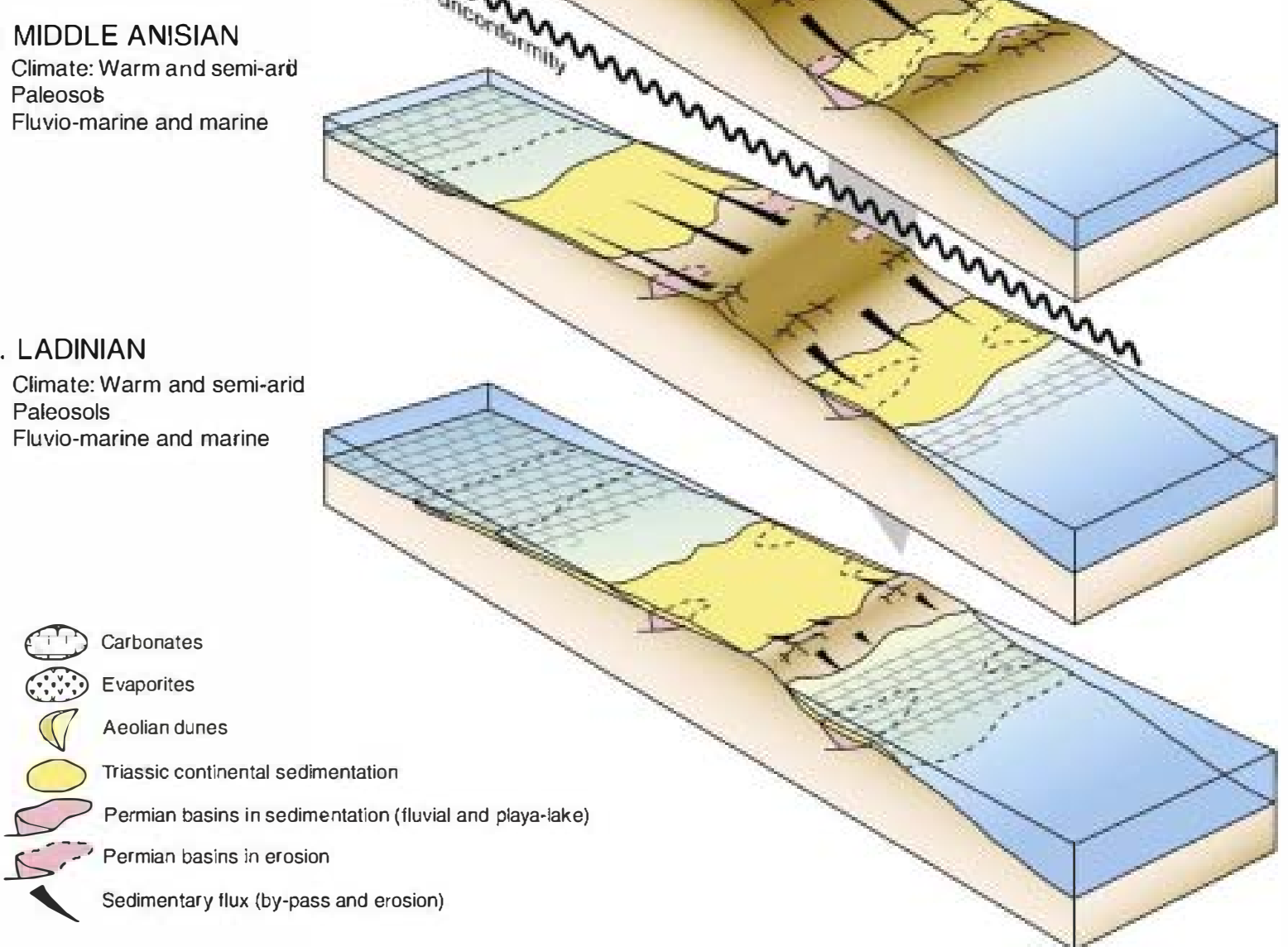

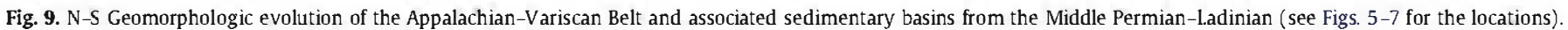


and/or a decrease in the subsidence of the depositional area, as demonstrated by numerical modelling (Heller and Paola, 1992; MarT et al., 2000; Paola, 2000; Paola et al., 1992). A strong clastic influx is well documented in the area of the Viling-Central Graben area (Geluk, 2005; Ziegler, 1990). Moreover, some basins located on the southem side of the Variscan Belt are mainly in erosion and/or there was no deposition during the Late Permian (Figs. 3, 4).

In the Laurasia supercontinent, three palaeogeographic units can be distinguished from the Early Triassic onwards: a northern domain separated from a southern one by an intra-belt domain (Figs. 6, 7). At the beginning of the Triassic times (Induan), sediments were mainly in by-pass throughout the western peri-Tethyan continental region. The sediment supply, coming from north of the Variscan Belt, was preserved only locally in low topographic areas (the Germanic Basin and North Sea: the residual Zechstein basin) under warm and subhumid/semi-arid climate conditions (Fig. 9B). In the southern part of the Variscan Belt, the sediment record does not seem to have been preserved, but could more probably be present in the Tethys Ocean as siliciclastic marine sediments. This would imply a large detrital discharge into the marine waters during the Late Permian and Induan (Figs. 6, 9B).

The earliest Mesozoic sediments preserved in the northern and southern endoreic extra-belt basins show a high mineralogical and textural maturity (well-rounded quartz and quartzite grains) indicating a long transport process. Moreover, in some of the southern basins, the Early Triassic palaeocurrent directions (Fig. 6) are different from those of the Middle-Late Permian (Fig. 7), attesting to a change of fluvial networks between these two periods. The intra-belt basins (Figs. 5-7) were under erosion during the entire Early Triassic and sometimes up to the Hettangian (Figs. 8, 9B to E). This implies that all the areas of sedimentation were filled up by the end of Permian and no new areas of subsidence developed during the Early Triassic in this intra-belt area.

In several basins of the northwestern Tethys margin (Paris Basin, Iberian Range, Sardinia; Figs. 2, 3), the development of the earliest Mesozoic palaeosol horizons during the upper Olenekian (Spathian) suggests one or more local hiatus(es) or a general slowing down of the sedimentation rate. The reactivation of the source area is demonstrated by a major change in the siliciclastic supply (rich in angular quartz and feldspars) and fluvial style. The restart of the sediment supply, with the reactivation of the source areas, began at the end of the Olenekian or the early Anisian. The new fluvial style, in an exhoreic context, was controlled by sea level variations (Fig. 9D). During the Anisian and Iadinian, continental sedimentation was characterised by a retrogradational trend, i.e. an evolution from fluvial systems to fluvio-marine environments. This is proof of the direct influence of the Tethys Ocean in the southern and northern domains (Figs. 8, 9E).

\subsubsection{Tectonic control}

Two phases of deformation can be inferred: (1) at the Late Permian-Early Triassic; and (2) at the top of the Early Triassic, the Hardegsen unconformity. The latter, which shows as an angular (lowangle) unconformity in the north, with onlap of the overlying deposits on the previous ones, is not more than a disconformity to the south.

Most authors believe that the Variscan Belt was under tectonic collapse during the Permian (e.g. Burg et al., 1994; Lorenz and Nicholls, 1976; Ménard and Molnar, 1988) and the discussion is about the duration of the related extension and, to a lesser extent, about the cause of the collapse. The Middle-Late Permian basins were created and developed during an extensional phase either during the development of some rift systems in Central and Western Europe and/or as the result of the reactivation of ancient Hercynian faults representing the initial phase of post-Variscan plate reorganisation (Arche and López-Gómez, 1996; Beauchamp, 1997; Brunet and Le Pichon, 1982; López-Gómez et al., 2005; Ziegler, 1990). In other respects, the sedimentological analysis of the Middle-Upper Permian (Figs 5, 9A) and Lower Triassic (Figs. 6, 7, 9B) deposits shows that the Permian-Triassic Boundary is mainly characterised by an erosional and in places an angular unconformity, except in the northern domain. Other main features of the study area are: (i) the important sedimentary supply in some extra-belt basins at the end of the Permian, (ii) the erosion stage and/or no deposition in some intra-belt basins during the uppermost Permian, (iii) the Early Triassic (Induan) epoch of sediment by-pass through all the continental systems (Fig. 9B), and (iv) the different palaeocurrent direction pattern between the Middle-Late Permian (Fig. 5) and Early Triassic (Fig. 7), which indicates a change of fluvial networks. These features indicate a period of relief rejuvenation during the Late Permian. This tectonic pulse implies an increase in sediment supply and/or erosion during the Iate Permian, which seems to occur earlier in the southern than in the northern area. The preservation of the Lower Triassic deposits (Induan-Olenekian) mirrors the progressive infilling of the basin morphologies inherited from the Iate Permian (Fig. 9B, C).

At the scale of the northwestern Tethys margin, the upper part of the Early Triassic is marked by a tectonic unconformity: the Hardegsen unconformity (Ziegler, 1990). During the Hardegsen phase, an important structural reorganisation occurred in NW Europe (Geluk, 2005; Geluk and Röhling, 1997). This led to the formation of the main rift in NW Germany and is attributable to the final collapse phase of the Variscan Belt (Best et al., 1983; Röhling, 1991). Above the unconformity, in the southern part of the Germanic Basin (NE France), the Triassic deposits show an onlap relationship with the underlying formations, which confirms tectonic activity just before the reorganisation of fluvial sedimentation. Moreover, the siliciclastic components of these fluvial sediments (Fig. 2) include micas, large feldspar crystals and angular quartz pebbles, thereby providing evidence for the reactivation of the source area. In the other basins where the Hardegsen unconformity is not recorded (Figs. 2-4), the earliest continental Anisian sediments (Fig. 9D) generally contain more micas and feldspar crystals. This confirms a reactivation at the scale of the entire study area. Within the southern domain (Fig. 3) and the eastern to central part of the northern domain (Figs. 2, 4), the AnisianLadinian successions are characterised by a vertical succession from fluvial to open marine sedimentation, which occurred during the Muschelkalk Sea transgression (Fig. 8). At a wider regional scale, the east-west transgression of the Tethys Ocean can be clearly observed (Figs. 8, 9D, E). Progressively, from the early Anisian-Middle Ladinian, the Germanic Basin was connected with the Tethys Ocean (Dercourt et al, 1993) and the fluvial systems were developed in an exorheic basin setting. Within the intra-belt domain, marine influence began either in the Ladinian or liassic depending on the location (Figs. 4, 8).

\subsection{Summary}

Palaeogeographic reconstructions of the continental northwestern peri-Tethys regions during the Middle Permian-Middle Triassic allow the different areas where sedimentation or erosion occurred to be characterised and show changes in the basin morphology, palaeodrainage networks and palaeorelief between the studied epochs. During this time interval, the continental realm, dominated by the Variscan Belt, can be divided into three parts (Fig. 9): two extra-belt domains (the northern and southern side areas) and one intra-belt domain. In this last sector, sediment accumulated during most of the Early-through-Middle Permian, while erosion and sediment transport occurred between the Late Permian and the beginning of the onset of Mesozoic sedimentation, dated as Anisian-to-Hettangian according to the location (Figs. 5-9).

An unconformity (angular in places) between the Late Permian and Early Triassic appears everywhere, except in the central part of the Germanic Basin (Figs. 2-4). The sedimentation gap is more developed in the southern area, where in some basins no Upper 
Permian sediments occur (Figs. 3, 4). A period of relief rejuvenation during the Late Permian is indicated by patterns of sediment supply or erosion in the uppermost Permian, the Early Triassic (Induan) epoch of sediment by-pass through all the continental systems (Fig. 9B), and the changing palaeocurrent direction pattern between the MiddleLate Permian (Fig. 5) and the Early Triassic (Fig. 7). During the Induan, all the intra-belt basins were under erosion and the other basins were prone to by-passing (Figs. 6, 9B). Thus, the sediment supply was only preserved in the north (the central part of the Germanic Basin) and probably in the Tethys Ocean as marine siliciclastic sediments. This implies a voluminous detrital input into the marine waters during the Late Permian and Induan.

In the northern and southern parts of the Variscan Belt, Mesozoic sedimentation began during the early Olenekian (Smithian; Figs. 7, 9C), with fluvial siliciclastics laid down under hyper-arid climatic conditions. The late Olenekian (Spathian) is characterised by the appearance of the first palaeosol horizons. During this time period, deformation induced the genesis of the Hardegsen unconformity as well as new source areas, and a new fluvial style, under marine influence. During the Anisian and Ladinian (Figs. 8, 9D, E) in the southern and northern domains, continental sedimentation is characterised by a vertical evolution from fluvial systems into fluvio-marine environments, indicating a direct influence from the Tethys Ocean.

\section{Acknowledgments}

We are grateful for the financial support of the INSU/CNRS programme "ECLIPSE II", entitled "Palaeogeographic and climatic impact on continental deposits during the post-crisis recovery by flora and fauna in the Lower and Middle Triassic" (coordinated by S. Bourquin and J. Broutin) and to the CGL2008-00093 Project (Ministry of Education and Sciences, Spain), "Iate Permian crisis events and Triassic recovery" (coordinated by J. López-Gómez). A. Ronchi's recent research in Sardinia was partly funded by PRIN 2008 grants (coordinated by G. Oggiano). We gratefully acknowledge Dr. M.C. Geluk and two anomynous reviewers for their critical and constructive reviews of the paper and S. Mullin for improving the English style. The authors thank Dr. W. A. DiMichele of the NMNH Smithsonian Institution for his careful review.

\section{References}

Aigner, T., Bachmann, G.H., 1992. Sequence-stratigraphic framework of the German Triassic. Sed. Geol. 80, 115-135.

Aigner, T., Homung, J., Junghans, W.D., Pöppelreiter, M., 1998. Baselevel cycles in the Triassic of the South-German Basin: a short progress report. Epicontinental Triassic, 1: In: Bachmann, G.H., lerche, I. (Eds.), Zbl. Geol Paläont. Teil, 1, pp. 537-544.

Alvarez-Ramis, C., Femández-Marrón, T., Calafat, F., 1995.Avance sobre la megaflora triásica, en facies germánica, de Estellencs (sector noroccidental de la Sierra de Tramontana, Mallorca): Rev. Esp. Palaeo. № Homenaje al Dr. Guillermo Colom, pp. 55-58.

Arche, A., López-Gómez, J., 1996. Origin of the Permian-Triassic Iberian Basin, centraleastern Spain. Tectonophysics 266, 443-464.

Arche,A., l.ópez-Gómez, J., 1999. Tectonic and geomorphic controls on the fluvial sty les of the Eslida Formation, Middle Triassic, Eastern Spain. Tectonophysics 315, 187-207.

Arche, A., lópez-Gómez, J., 2005. Sudden changes in fluvial style across the PermianTriassic boundary in the eastern Iberian Ranges, Spain: analysis of possible causes. Palaeogeogr. Palaeoclimatol. Palaeoecol. 229, 104-126.

Arche, A., lópez-Gómez, J., Marzo, M., Vargas, H., 2004. The siliciclastic Permian-Triassic deposits in Central and Northeastern Iberian Peninsula (Iberian, Ebro and Catalan Basins): a proposal for correlation. Geol. Acta 2, 305-320.

Arribas, J., 1984. Sedimentología y diagénesis del Buntsandstein y Muschelkalk de la Rama Aragonesa de la Cordillera Ibérica (Provincias de Soria y Zaragoza). Ph.D. thesis, Univ. Complutense, Madrid.

Autran, A., l.efort,J.P., Debeglia, N., Edel, J.B., Vigneresse, J.L., 1994. Gravity and magnetic expression of terranes in France and their correlation beneath overstep sequences. In: Keppie, J.D. (Ed.), Pre-Mesozoic Geology in France and related areas. Springer, Berlin, pp. 49-72.

Beauchamp, B., 1997. The P-T and other stress-release events in NW Pangea. Pangea (abs.). Gaea Heidelb. 3, 1-68.

Bercovici, A., Diez, J.B., Broutin, J., Bourquin, S., linol, B., Villanueva-Amadoz, U., l.ópezGómez, J., Durand, M., 2009. Palaeobotanical aspects of the Upper Permian (Thuingian) of Minorca (Balearic island-Spain): biostratigraphical, biogeographical and palaeoclimatic implications. Rev. Palaeobot. Palynol. 158, 14-28. Geol. Mijnbouw 62, 25-34.

Bixel, F., 1987. l.e volcanisme stéphano-permien des Pyrénees pétrographie, minéralogie, géochimie. Cuad. Geol. Ibér. 11, 41-55.

Bixel, F., l.ucas, C., 1987. Approche géodynamique de Permien et du Trias des Pyrénées dans le cadre du Sud-Ouest européen. Cuad. Geol. Ibér. 11, 57-81.

Bourges, P., Rolando, J.P., Souquet, P., 1987. Le Permien de la partie occidentale du Détroit de Rodez (France): systèmes de dépôt, dynamique du bassin. Ann. Soc. Géol. Nord 106, 173-182.

Bourquin, S., Durand, M., Diez, J.B., Broutin, J., Fluteau, F., 2007. The Permian-Triassic boundary and lower Triassic sedimentation in the Western European basins: an overview. J. Iber. Geol. 33, 221-236.

Bourquin, S., Guillocheau, F., Péron, S., 2009. Braided river within an arid alluvial plain (example from the Early Triassic, Western German Basin): criteria of recognition and expression of stratigraphic cycles. Sedimentology 56, 2235-2264.

Bourquin, S., Péron, S., Durand, M., 2006. lower Triassic sequence stratigraphy of the western part of the Germanic Basin (west of Black Forest): fluvial system evolution through time and space. Sed. Geol. 186, 187-211.

Bourrouilh, R., 1973. Stratigraphie, sédimentologie et tectonique de l'Ile de Minorque et du Nord-Est de Majorque (Baléares) - la terminaison nord-orientale des Cordillères Bétiques en Méditerranée occidentale. Ph.D. thesis, Univ. Paris VI.

Bray ard, A., Bucher, H., Escarguel, G., Fluteau, F., Bourquin, S., Galf etti, T., 2006. The Early Triassic ammonoid recovery: palaeoclimatic significance of diversity gradients. Palaeogeogr. Palaeoclimatol. Palaeoecol. 239, 374-395.

Brocard, C., Philip, J., 1989. Précisions stratigraphiques sur le Trias de la Provence orientale. Conséquence structurales et paléogéographiques. Géologie de la France: Bulletin B.R.G.M., 3, pp. 27-32.

Brookfield, M.E., 2008. Palaeoenvironments and palaeotectonics of the arid and hyperarid intracontinental latest Permian-late Triassic Solway Basin (U.K.). Sed. Geol. $210,27-47$

Broutin, J., Diez, J.B., Durand, M., 2002. Macro- and microfloral content of the "les Salettes Formation" uppermost member (Permian Toulon Basin, southeastern France). Biostratigraphic implications. 6th European Paleobotany-Palynology Conference, University Athens, Greece, pp. 61-62.

Broutin, J., Doubinger, J., Gisbert, J., Satta-Pasini, S., 1988. Permières datations paly nologiques dans les faciès Buntsandstein des Pyrénées catalanes espagnoles. C. R. Acad. Sci., Paris, Ser. 2 (306), 159-163.

Broutin, J., Ferrer, J., Gisbert, J., Nmila, A., 1992. Première découverte d'une microflore thuringienne dans les faciès saxonien de l'Ile de Minorque (Baléares, Espagne). C.R. Acad. Sci., Paris, Ser. 2 (315), 117-122.

Brunet, M.-F., Le Pichon, X., 1982. Subsidence of the Paris Basin. J. Geophys. Res. 87 (B10), 8547-8560.

Burg, J.P., Van den Driessche, J., Brun,J.P., 1994. Syn- to post-thickening extension in the Variscan Belt of Western Europe: modes and structural consequences. Géol. Fr. 3, 33-51.

Calafat, F.J., 1988. Estratigrafia y sedimentologia de la litofacies Buntsandstein de Mallorca. Ph.D. thesis, Univ. Illes Balears y Univ. Barcelona.

Calvet, F., Márquez, L., Trifonova, E., 1994. litoestratigrafía y bioestratigrafía (foraminíferos) de las facies Muschelkalk del Triásico sudpirenaico y del Pirineo Vasco-Cantábrico (España). Bol. Real Soc. Esp. Hist. Nat. (Geol.) 89, $167-188$

Calvet, F., Marzo, M., 1994. El Triásico de las Cordilleras Costero Catalanas. Estratigrafia, Sedimentología y Análisis Secuencial. Field Guide, III Coloquio de Estratigrafía y Sedimentología del Pérmico y Triasico de España, Cuenca.

Calvet, F., Solé de Porta, N., Salvany, J.M., 1993. Cronoestratigrafía (Palinología) del Triásico sudpirenaico y del Pirineo Vasco-Cantábrico. Acta Geol Hisp. 28 (4), 33-48.

Carrillat, A., Martini, R., Zaninetti, L., Cirilli, S., Gandin, A., Vrielinck, B., 1999. The Muschelkal (Middle to Upper Triassic) of the Monte di Santa Giusta (NW Sardinia): sedimentology and biostratigraphy. Eclogae Geol. Helv. 92, 81-97.

Cassinis, G., Durand, M., Ronchi, A., 2003. Permian-Triassic continental sequences of Northwest Sardinia and South Provence: stratigraphic correlations and palaeogeographical implications. Boll. Soc. Geol. Ital. Spec. 2, 119-129.

Cassinis, G., Durand, M., Ronchi, A., 2007. Remarks on the Permian-Triassic transition in Central and Eastern lombardy (Southern Alps, Italy). J. Iber. Geol. 33, 133-142.

Châteauneuf, J.J., Farjanel, G., 1989. Sy nthèse géologique des bassins permiens français. Mém. Bur. Rech. Géol. Min. 128.

Chen, Y., Henry, B., Faure, M., Becq-Giraudon, J.-F., Talbot, J.-Y., Daly, L., Le Goff, M., 2006. New Early Permian paleomagnetic results from the Brive Basin (French Massif Central) and their implications for late Variscan tectonics. Int. J. Earth Sci. (Geol. Rundsch.) 95, 306-317.

Clemmensen, L.B., 1979. Triassic lacustrine red-beds and palaeoclimate: the "Buntsandstein" of Helgoland and the Malmros Klint Member of East Greenland. Geol. Rundsch. 6, 748-774.

Clemmensen, L.B., 1991. Controls on aeolian sand sheet formation exemplified by the lower Triassic of Helgoland. Acta Mech. Suppl. 2, 161-170.

Clemmensen, L.B., Tirsgaard, H., 1990. Sand-drift surf aces: a neglected type of bounding surface. Geology 18, 1142-1145.

Courel ( coord.) et al, 1984. Trias. In: Debrand-Passard, S., Courbouleix, S., lienhardt, M.J. (Eds.), Synthèse géologique du Sud-Est de la France. Mém. Bur. Rech. Géol. Min. 125, pp. $61-118$.

de la Horra, R., 2008. Variaciones mineralógicas, geoquímicas, bióticas del Pérmico Superior en el sudeste de la Cordillera Ibérica: implicationes paleogeográficas y paleoclimáticas. Ph.D. Thesis Univ. Complutense Madrid, Spain.

de la Horra, R., lópez-Gómez, J., Arche, A., 2005. Caracterización de la unidad Conglomerados de Valdemeca en la transición Pérmico-Triásico de la Cordillera Ibérica centro-oriental. Geo-Temas 8, 141-145. 
Demathieu, G., Durand, M., 1991. Ies traces de pas de Tétrapodes dans le Trias détritique du Var et des Alpes-Maritimes France: Bull Mus. Natl. Hist. Nat. Paris, C13, pp. 115-133.

Dercourt, J., Gaetani, M., Vrielynck, B., Barrier, E., Biju-Duval, B., Brunet, M.F., Cadet, J.P., Crasquin, S., Sandulescu, M., 2000. Atlas Peri-Tethys - Paleogeographical maps CCGM / CGMW Paris.

Dercourt, J., Ricou, L.E., Vrielynck, B., 1993. Atlas Tethys palaeoenvironmental maps Beicip-Franlab Rueil Malmaison.

Diéguez, C., Barron, E., 2005. Iate Permian flora and vegetation changes near the Permian-Triassic boundary in the Iandete section of the Alcotas Formation (SE Iberian Ranges, Spain). Palaeogeogr. Palaeoclimatol. Palaeoecol. 229, 54-68.

Diéguez, C, de la Horra, R., l.ópez-Gómez, J., Benito, M.I., Barrenechea, J., Arche, A. l.uque, J., 2007. late Permian plant remains in the SE Iberian Ranges, Spain: biodiversity and palaeovegetational significance. C.R. Palevol 6, 403-411.

Diez, J.B., 2000. Geología y Paleobotánica de la Facies Buntsandstein en la Rama Aragonesa de la Cordillera Ibérica. Implicaciones bioestratigráficas en el Peritethys Occidental. Ph.D. Thesis Univ. Zaragoza and Univ. Paris-6.

Diez, J.B., Bourquin, S., Broutin, J., Ferrer, J., 2007. The Iberian Permian Triassic 'Buntsandstein' of the Aragonian Branch of the Iberian range (Spain) in the WestEuropean sequence stratigraphical framework: a combined palynological and sedimentological approach. Bull. Soc. Géol. Fr. 178 (3), 179-195.

Diez, J.B., Broutin, J., Ferrer, J., 2005. Difficulties encountered in defining the PermianTriassic boundary in Buntsandstein facies of the western Peritethy an domain based on paly nological data. Palaeogeogr. Palaeoclimatol. Palaeoecol. 229, 40-53.

Diez, J.B., Grauvogel-Stamm, L., Broutin, J., Ferrer, J., Gisbert, J., l.iñán, E., 1996. Premiere découverte d'une paléoflore anisienne dans le facies "Buntsandstein" de la Branche aragonaise de la Cordillere Ibérique Espagne. C.R. Acad. Sci., Paris, Ser. 2 (323) $341-347$

Dinarès-Turell, J., Diez, J.B., Rey, D., Arnal, I., 2005. "Buntsandstein" magnetostratigraphy and biostratigraphic reappraisal from eastern Iberia: Early and Middle Triassic stage boundary definitions through correlation to Tethyan sections Palaeogeogr. Palaeoclimatol. Palaeoecol. 229, 158-177.

Doubinger, J., López-Gómez, J., Arche, A., 1990. Pollen and spores from the Permian and Triassic sediments of the Southeastern Iberian ranges, Cueva de Hierro (Cuenca) to Chelva-Manzanera (Valencia-Teruel) region, Spain. Rev. Palaeobot. Palynol. 66, 25-45.

Durand, M., 1972. Répartition desgalets éolisés dans le Buntsandstein moyen lorrain. C.R. Somm. Soc. Géol. Fr. 5, 214-215

Durand, M., 1978. Paléocourants et reconstitution paléogéographique: l.exemple du Buntsandstein des Vosges méridionales (Trias inf érieur et moyen continental): Sci. Terre Nancy, 22, pp. 301-390.

Durand, M., 1993. Un exemple de sédimentation continentale permienne dominée par l'activité de chenaux méandriformes: la Formation de Saint-Mandrier (Bassin de Toulon, Var). Géol. Fr. 2, 43-55.

Durand, M., 2006. The problem of the transition from the Permian to the Triassic Series in southeastern France: comparison with other Peritethyan regions. Non-Marine Permian Biostratigraphy and Biochronology: In: l.ucas, S.G., Cassinis, G., Schneider, J.W. (Eds.), Geol. Soc. Spec. Publ., 265, pp. 281-296.

Durand, M. 2008. Permian to Triassic continental successions in southern Provence (France): an overview. Boll. Soc. Geol. Ital. (Ital.J. Geosci.) 127, 697-716.

Durand, M., Chrétien, J.C., Poinsignon, J.M., 1994. Des cônes de déjection permiens au grand fleuve triasique: Evolution de la sédimentation continentale dans les Vosges du Nord autour de - $250 \mathrm{Ma}$. Livret-guide d'excursion Congrès National de I'Assoc Prof. Biol. Geol. Editions Pierron Sarreguemines.

Durand, M., Jurain, G., 1969. Eléments paléontologiques nouveaux du Trias des Vosges méridionales. C.R. Acad. Sci., Paris 269 D, 1047-1049.

Durand, M., Meyer, R., 1982. Silicifications (silcrètes) et évaporites dans la Zone-limite violette du Trias inf érieur lorrain Comparaison avec le Buntsandstein de Provence et le Permien des Vosges. Sci. Géol. Bull. Strasb. 35, 17-39.

Durand, M., Meyer, R., Avril, G., 1989. l.e Trias détritique de Provence, du dôme de Barrot et du Mercantour: Publ. Assoc. Sédimentol. Fr. 6, Paris.

Duringer, P., Hagdorn, H., 1987. l.a zonation par cératites du Muschelkalk supérieur lorrain (Trias, Est de la France). Diachronisme des faciès et migration vers I'Ouest du dispositif sédimentaire. Bull. Soc. Géol. Fr. 8 (3), 601-609.

Edel, J.B., Dubois, D., Marchant, R., Hernández, J. Cosca, M. 2001. la rotation miocène inf érieur du bloc corso-sarde. Nouvelles contraintes paléomagnétiques sur la fin du mouvement. Bull. Soc. Géol. Fr. 172, 275-283.

Edwards, RA, Warrington, G. Scrivener, R.C. Jones, N.S , Haslam, HW., Ault, L. 1997. The Exeter Group, south Devon, England: a contribution to the early post-Variscan stratigraphy of northwest Europe. Camb. Univ. Press 134 (2) $177-197$

Fluteau, F., Besse, J., Broutin, J., Berthelin, M., 2001. Extension of Cathaysian flora during the Permian. Climatic and paleogeographic constraints. Earth Planet. Sci. l.ett. 193, $603-616$

Fuglewicz, R., 1980. Stratigraphy and palaeogeography of the Iower Triassic in Poland on the basis of megaspores. Acta Geol. Pol. 30, 417-470

Gall, J.C., 1971. Faunes et paysages du Grès à Voltzia du Nord des Vosges. Essai paléoécologique sur le Buntsandstein supérieur: Mém. Serv. Carte géol. Als.-Iorr., 34

Gall, J.C., Durand, M., Müller, E., 1977. L.e Trias de part et d'autre du Rhin: corrélations entre les marges et le centre du Bassin germanique. Bull. Bur. Rech. Géol. Min. Sect. IV 3, 193-204.

Gand, G., 1987. Ies traces de Vertébrés tétrapodes du Permien français (paléontologie, stratigraphie, paléoenvironnements). Thèse d'État ès Sciences Naturelles Univ. de Bourgogne.

Gand, G., Durand, M., 2006. Tetrapod footprint ichnoassociations from French Permian basins. Comparison with other Euramerican ichnofaunas. Non-marine Permian Biostratigraphy and Biochronology: In: l.ucas, S., Cassinis, G., Schneider, J.W. (Eds.) Geol. Soc. Spec. Publ., 265, pp. 157-177. Taphonomic trends of macrofloral assemblages across the Permian-Triassic boundary, Karoo Basin. Palaios 20, 479-497.

Geluk, M.C., 1998. Palaeogeographic and structural development of the Triassic in the Netherlands - new insights. Epicontinental Triassic, 1: In: Bachmann, G.H., Ierche, l. (Eds.), Zbl. Geol. Paläont. Teil, 1, pp. 545-570.

Geluk, M.C., 2005. Stratigraphy and tectonics on Permo-Triassic basins in the Netherlands and surrounding areas. Ph.D. thesis Univ. Utrecht Netherlands

Geluk, M.C. Röhling, H.G., 1997. High-resolution sequence stratigraphy of the lower Triassic "Buntsandstein" in the Netherlands and Northwestern Germany. Geol. Mijnbouw 76, 227-246

Gisbert, A.J., 1983. El Pérmico de los Pirineos españoles. In: Martínez, C. (Ed.), Carbonífero y Pérmico de España. IGME Madrid, pp. 403-420.

Glennie, K.W., Buller, A.T., 1983. The Permian Weissliegend of NW Europe: the partial deformation of aeolian dune sands caused by the Zechstein transgression. Sed Geol. 35, 43-81.

Glennie, K.W., Higham, J., Stemmerik, L., 2003. The Permian of the Northern North Sea In: Evans, D., Graham, C., Armour, A., Bathurst, P. (Eds.), The Millennium Atlas: Petroleum geology of the Central and Northern North Sea. Geological Society london, pp. $91-103$.

Goldsmith, P.J., Hudson, G., van Veen, P., 2003. Triassic. In: Evans, D., Graham, C. Armour, A., Bathurst, P. (Eds.), The Millennium Atlas: Petroleum geology of the Central and Northern North Sea. Geological Society l.ondon, pp. 105-127.

Goldsmith, P.J., Rich, B., Standring, J., 1995. Triassic correlation and stratigraphy in the South Central Graben, UK North Sea. Permian and Triassic Rifting in Northwest Europe: In: Boldy, S.A.R. (Ed.), Geol. Soc. Spec. Publ., 91, pp. 123-143.

Gómez-Gras, D., 1993. El Permotrías de las Baleares y de la vertiente mediterr ánea de la Cordillera Ibérica y del Maelstrat: Facies y petrología sedimentaria (Parte Il). Bol. Inst. Geol. Min. Esp. 104, 467-515.

Gómez-Gras, D., Alonso-Zarza, A.M., 2003. Reworked calcretes: their significance in the reconstruction of alluvial sequences (Permian and Triassic, Minorca, Balearic Islands, Spain). Sed. Geol. 158, 299-319.

Grauvogel-Stamm, L., Álvarez Ramis, C., 1996. Conifères et pollen insitu du Buntsandstein de l'île de Majorque (Baléares, Espagne). Cuad. Geol. Ibér. 20, 229-243.

Grebe, H., 1957. Zur Mikroflora des niederrheinischen Zechstein. Geol. Jb 73, 51-74.

Grebe, H., Schneider, H.J., 1962. Die Sporae dispersae des niederrheinischen Zechsteins Fortschr. Geol. Rheinl. Westfalen 12, $201-224$

Heller, P.L., Paola, C, 1992. The large-scale dy namics of grain-size variation in alluvial basins, 2: Application to syntectonic conglomerate. Basin Res. 4, 91-102.

Hounslow, M.W., McIntosh, G., 2003. Magnetostratigraphy of the Sherwood Sandstone Group (Iower and Middle Triassic), South Devon, UK: detailed correlation of the marine and non-marine Anisian. Palaeogeogr. Palaeoclimatol. Palaeoecol. 193, 325-348.

Hounslow, M.W., Ruffell, A.H., 2006. Triassic: seasonal rivers, dusty deserts and saline lakes, In: Brenchley, P.J., Rawson, P.F. (Eds.), The Geology of England and Wales, 2nd edition. Geological Society l.ondon, pp. 295-324.

Kozur, H., 1998. The correlation of the Germanic Buntsandstein and Muschelkalkwithin the Tethy an scale. Epicontinental Triassic, 1: In: Bachmann, G.H., l.erche, l. (Eds.) Zbl. Geol. Paläont. Teil, 1, pp. 701-725.

Kozur, H., 2003. Integrated ammonoid, conodont and radiolarian zonation of the Triassic and some remarks to stage/substage subdivision and the numeric age of the Triassic stages. Albertiana 28, 57-74.

Kozur, H.W., Bachmann, G.H., 2008. Updated correlation of the Germanic Triassic with the Tethyan scale and assigned numeric ages. Ber. Geol. B.-A. Wien 76.

Iegler, B., Schneider,J.W., 2008. Marine ingressions into the Middle/late Permian saline lake of the Southern Permian Basin (Rotliegend, Northern Germany) possibly linked to sea-level highstands in the Arctic rif t system. Palaeogeogr. Palaeoclimatol. Palaeoecol. 267, 102-114

Ieonard, A.J., Moore, A.G., Selwood, E.B., 1982. Ventifacts from a deflation surface marking the top of the Budleigh Salterton Pebble beds, East Devon. Proceedings of the Ussher Society 5,333 .

Linol, B., Bercovici, A., Bourquin, S., Diez, J.B., López-Gómez, J., Broutin, J., Durand, M., Villanueva-Amadoz, U., 2009. Palaeogeographical reconstructions of Uppe Permian to Middle Triassic of South-Western European basins: new sedimentological data from Minorca Balearic Islands, Spain. Sed. Geol. 220, 77-94.

Llompart, C., Rosell, J., Márquez-Aliaga, A., Goy, A., 1987. El Muschelkalk de la isla de Menorca. Cuad. Geol. Ibér. 11, 323-337.

Iopez, M., Gand, G., Garnic, J., Körmer, F., Schneider, J., 2008. The playa environments of the Iodève Permian Basin (Iangedoc-France). J. Iber. Geol. 34 (1), 29-56

López-Gómez, J., Arche, A., Pérez-lópez, A., 2002. Permian and Triassic. In: Gibbons, W., Moreno, T. (Eds.), The Geology of Spain. Geological Society london, pp. 185-212.

López-Gómez, J., Arche, A., 1994. El Triásico y Pérmico del SE de la Cordillera Ibérica. III Coloquio de Estratigrafía y Paleogeografía del Pérmico y Triásico Espana, Cuenca Guia de excursion.

López-Gómez, J., Arche, A., Calvet, F., Goy, A., 1998. Epicontinental marine carbonate sediments of the Middle and Upper Triassic in the Westernmost part of the Tethys Sea, Iberian Peninsula. Epicontinental Triassic, 2: In: Bachmann, G.H., l.erche, I (Eds.), Zbl. Geol. Paläont. Teil 1, 9-10, pp. 1033-1084.

lópez-Gómez, J., Arche, A., Marzo, M., Durand, M., 2005. Stratigraphical and palaeogeographical significance of the continental sedimentary transition across the Permian-Triassic boundary in Spain. Palaeogeogr. Palaeoclimatol. Palaeoecol. 229, 3-23.

lorenz, V., Nicholls, 1.A., 1976. The permocarboniferous basin and range Province of Europe. An application of plate tectonics. In: Falke, H. (Ed.), The Continental Permian in Central West, and South Europe. D. Reidel Publ. Comp., Dordrecht, pp. 313-342. 
Iozovsky, V.R., Krassilov, V.A., Afonin, S.A., Burov, B.V., Yaroshenko, O.P., 2001. Transitional Permian-Triassic deposits in European Russia, and non-marine correlations. Permian Continental Deposits of Europe and Other Areas. Regional Reports and Correlations: In: Cassinis, G. (Ed.), Natura Bresciana Monografia, 25, pp. 301-310.

Mader, D., l.aming, D., 1992. South Devon (England): New Red Sandstone (Upper Caboniferous, Permian and Triassic). In: Mader, D. (Ed.), Evolution of palaeoecology and palaeoenvironment of Permian and Triassic fluvial bassins in Europe. Volume 1: estern and eastern Europe. Fischer Verlag, pp. 15-225.

March, M., 1991. los conodontos del Triasico Medio (Facies Muschelkalk) del Noreste de la Península Ibérica y de Menorca. Ph.D. thesis Univ. Valéncia (Unpublished).

Márquez, L., l.ópez-Gómez, J., Trifonova, E., 1994. Datación (foraminíferos) y ambientes sedimentarios de la Formación Dolomías de l.andete, Anisiense, Facies Muschelkalk, provincia de Cuenca. Bol. Real Soc. Esp. Hist. Nat. (Geol.) 89, 99-107.

Márquez, L., Trifonova, E., Calvet, F., 1992. An involutinidae (foraminifera) assemblage of Upper l.adinian (Muschelkalk Facies) of the Southern Pyrenees (Spain). In: Takayanagy, Y., Saito, T. (Eds.), Studies in Benthic Foraminif era, BENTHOS '90. Tokai University Press, pp. $355-360$.

Márquez-Aliaga, A., Valenzuela-Ríos, J.l., Calvet, F., Budurov, K., 2000. Middle Triassic conodonts from northeastern Spain: biostratigraphic implications. Terra Nova 12 , $77-83$.

Marr, J.G., Swenson, J.B., Paola, C., Voller, V.R., 2000. A two-diffusion model of fluvial stratigraphy in closed depositional basins. Basin Res. 12, 381-398.

Marzo, M., 1980. El Buntsandstein de los Catalánides. Estratigrafia y procesos de sedimentación. Ph.D. thesis Univ. Barcelona Spain.

Mascle, A., 1990. Géologie pétrolière des basins permiens français. Comparaison avec les bassins permiens du Nord de l'Europe. Chron. Rech. Min. 499, 69-86.

Mégnien, C, 1980. Tectonogenèse du Bassin de Paris: étapes de l'évolution du bassin. Bull. Soc. Géol. France 22, 669-680.

Ménard, G., Molnar, P., 1988. Collapse of a Hercynian Tibetan Plateau into a late Palaeozoic European Basin and Range province. Nature 334 (6179), 235-237.

Müller, E.M., 1954. Beiträge zur Kentniss der Stratigraphie und Paläogeographie des Oberen Buntsandsteins im Saar-Iotharingischen Raum. Ann. Univ. Sarav. Sci. III 3, $176-201$.

Muttoni, G., Gaetani, M., Budurov, K., Zagorchev, I., Trifonova, E., Ivanova, D., Petrunova, L., l.owrie, W., 2000. Middle Triassic paleomagnetic data from northern Bulgaria: constraints on Tethyan magnetostratigraphy and paleogeography. Palaeogeogr. Palaeoclimatol. Palaeoecol. 160, 223-237.

Ortlam, D., 1967. Fossile Böden als Leithorizonte für Gliederung des Höheren Buntsandsteins im nördlichen Schwarzwald und südlichen Odenwald. Geol. Jb $84,485-590$.

Ouyang, S., Norris, G., 1999. Earliest Triassic (Induan) spores and pollen from the Junggar Basin, Xinjiang, northwestern China. Rev. Palaeobot. Palynol. 106, 1-56.

Paola, C, 2000. Quantitative models of sedimentary basin filling. Sedimentolgy 47 (suppl.1), 121-178.

Paola, C., Heller, P.L., Angevine, C.L., 1992. The large-scale dynamics of grain-size variation in alluvial basins, 1: Theory. Basin Res. 4, 73-90.

Pecorini, G., 1962. Nuove osservazioni sul Permico della Nurra (Sardegna nordoccidentale). Atti Accad. Naz. lincei, Rend. Cl. Fis. Mat. e Nat. 8 (32), 377-380.

Péron, S., Bourquin, S., Fluteau, F., Guillocheau, F., 2005. Paleoenvironment reconstructions and climate simulations of the Early Triassic: impact of the water and sediment supply on the preservation of fluvial systems. Geodin. Acta 18 , $431-446$

Perrodon, A., Zabeck, J., 1990. Paris Basin. Interior Cratonic Basins: In: leighton, M.W., Kolata, D.R., Oltz, D.F., Eidel, J.J. (Eds.), AAPG Mem., 51, pp. 633-679.

Pittau, P., Del Rio, M., 2002. Palynofloral biostratigraphy of the Permian and Triassic sequences of Sardinia. Rend. Soc. Paleontol. Ital. 1, 93-109.

Posenato, R., Simone, L., Urlichs, M., Ibba, A., 2002. The l.adinian Muschelkalk of Punta del l.avatoio (Alghero, NW Sardinia). Rend. Soc. Paleontol. Ital. 1, 283-291.

Ramos, A., 1979. Estratigrafíay paleogeografía del Pérmico y Triásico al oeste de Molina de Aragón (Provincia de Guadalajara). Semin. Estratigrafig., Ser. Monogr. 6.

Ramos, A., Doubinger, J., 1989. Premières datations palynologiques dans le faciès Buntsandstein de l'île de Majorque (Baléares, Espagne). C.R. Acad. Sci., Paris, Ser. 2 (309), 1089-1094.

Renevier, E., 1874. Tableau des terrains sédimentaires formés pendant les époques de la phase organique du globe terrestre avec leurs représentants en Suisse et dans les régions classiques, leurs synonymies et les principaux fossiles de chaque étage. Bull. Soc. Vaud. Sci. Nat. 12, 218-252.

Richter-Bernburg, G., 1955. Stratigraphische Gliederung des deutschen Zechsteins. Z. Deut. Geol. Ges. 105, 593-645.

Richter-Bernburg, G., 1974. Stratigraphische Synopsis des deutschen Buntsandsteins. Geol.Jb 25, 127-132.

Röhling, H.G., 1991. A lithostratigraphic subdivision of the Iower Triassic in the Northwest German Iowlands and the German sector of the North Sea, based on gamma-ray and sonic logs. Geol. Jb A119, 3-24.

Rolando, J.P., Doubinger, J., Bourges, P., Iegrand, X., 1988. Identification de l'Autunien supérieur, du Saxonien et du Thuringien inf érieur dans le bassin de Saint-Affrique (Aveyron, France): Corrélations séquentielles et chronostratigraphiques avec les bassins de Iodève (Hérault) et de Rodez (Aveyron). C.R. Acad. Sci., Paris, Ser. 2 (307), $1459-1464$

Ronchi, A., 2004. Iate Palaeozoic to Early Mesozoic tectonosedimentary cycles in Sardinia and their correlation in the western Mediterranean area. Rocky Mountain (56th Annual) and Cordilleran (100th Annual) Joint Meeting (May 3-5) Geological Society of America Abstracts with Programs 36, 4, p. 83.
Ronchi,A., Broutin, J., Diez, J.B., Freytet, P., Galtier,J., Lethiers, F., 1998. New paleontological discoveries in some Early Permian sequences of Sardinia. Biostratigraphic and paleogeographic implications. C.R. Acad. Sci., Paris, Ser. Ila 327, 713-719.

Ronchi, A., Sarria, E., Broutin, J., 2008. The "Autuniano Sardo": basic features for a correlation through the Western Mediterranean and Paleoeurope. Boll. Soc. Geol Ital. (Ital. J. Geosci.) 127, 655-681.

Rosell,J., Arribas, J., Elizaga, E., Gómez-Gras, D., 1988. Caracterización sedimentológicay petrográfica de la serie roja Permo-Triásica de la Isla de Menorca. Bol. Inst. Geol. Min. Esp. 99, 71-82.

Rosell, J., Gómez-Gras, D., 1990. Mapa y memoria explicative de las Hojas (618-I-II) Fornellsy (618-III)-Ciutadella del Mapa Geológico Nacional a escala 1: 25.000. ITGE Madrid.

Rosell, J., Gómez-Gras, D., Elizaga, E., 1987. Mapa Geológico de España, escala 1:25.000 (segunda serie, primera edición), 647, Illa D'En Colom (cuadrante 647-IV), Maó (cuadrante 647-III) L.T.G.E. Madrid

Ruffell, A.H., Shelton, R.G., 2009. Permain to l.ate Triassic post-orogenic collapse, early Atlantic rifting, deserts, evaporating seas and mass extinctions. In: Woodcock, N., Strachan, R. (Eds.), Geological History of Britain and Ireland. Blackwell Publishing, pp. 297-313.

Rygel, M.C., Gibling, M.R., Calder, J.H., 2004. Vegetation-induced sedimentary structures from fossil forests in the Pennsylvanian Joggins Formation, NovaScotia. Sedimentology 51, 531-552.

Schneider,J.W., Körner, F., Roscher, M., Kroner, U., 2006. Permian climate development in the northern peri-Tethys area - the Iodève basin, French Massif Central, compared in an European and global context. Palaeogeogr. Palaeoclimatol. Palaeoecol. 240, 161-183.

Schweitzer, H.J., 1986. The land flora of the English and German Zechstein sequences. Geol. Soc. Iond. Spec. Publ. 22, 31-54.

Selwood, E.B., Edwards, R.A., Simpson, S., Chester, J.A., Hamblin, R.J.O., Henson, M.R., Riddolls, B.W., Waters, R.A., 1984. Geology of the country around Newton Abbot. Mem. Br. Geol. Surv. 339.

Shannon, P.M., 1995. Permo-Triassic development of the Celtic Sea region, offshore Ireland. Permian and Triassic Rifting in Northwest Europe: In: Boldy, S.A.R. (Ed.), Geol. Soc. Spec. Publ., 91, pp. 215-237

Shu, O., Norris, G., 1999. Earliest Triassic (Induan) spores and pollen from the Junggar Basin, Xinjiang, northwestern China. Rev. Palaeobot. Paly nol. 106, 1-56.

Smith, D.B., Taylor, J.C.M., Arthurton, R.S., Brookfield, M.E., Glennie, K.W., 1992 Permian. Atlas of palaeogeography and lithofacies: In: Cope, J.C.W., Ingham, J.K., Rawson, P.F. (Eds.), Mem. Geol. Soc. l.ondon, 13, pp. 87-96.

Sopeña, A., Sánchez-Moya, Y., 2004. l.as cuencas continentales de la orogenia varisca. In: Vera, J. (Ed.), Geología de España. SGE-IGME Madrid, pp. 479-481.

Swiecicki, T., Wilcockson, P., Canham, A., Whelan, G., Homann, H., 1995. Dating, correlation and stratigraphy of Triassic sediments in the West Shetlands area. Permian and Triassic Rifting in Northwest Europe: In: Boldy, S.A.R. (Ed.), Geol. Soc Spec. Publ., 91, pp. 57-85.

Szurlies, M., 2004. Magnetostratigraphy: the key to a global correlation of the classic Germanic Trias - case study Volpriehausen Formation Middle Buntsandstein, Central Germany. Earth Planet. Sci. Iett. 227, 395-410.

Szurlies, M., 2007. Iatest Permian to Middle Triassic cyclo-magnetostratigraphy from the Central European Basin, Germany: Implications for the geomagnetic polarity timescale. Earth Planet. Sci. l.ett. 261, 602-619.

Szurlies, M., Bachmann, G.H., Menning, M., Nowaczyk, N.R., Käding, K.C, 2003. Magnetostratigraphy and high-resolution lithostratigraphy of the Permian-Triassic boundary interval in Central Germany. Earth Planet. Sci. lett. 212, 263-278.

Trusheim, F., 1961. Über Diskordanzen im mitlleren Buntsandstein Norddeutschlands zwischen Weser und Ems. Erdöl-Zeitschrift 77, 361-367.

Trusheim, F., 1963. Zur Gliederung des Buntsandsteins. Erdöl-Zeitschrift 79, 277-292.

Ulicny, D., 2004. A drying-upward aeolian system of the Bohdašin Formation (Early Triassic), Sudetes of NE Czech Republic: record of seasonality and long-term palaeoclimate change. Sed. Geol. 167, 17-39.

Vachard, D., Colin, D., 1994. Etude micropaléontologique et palynologique du "Muschelkalk"de Minorque (Trias, lles Baléares, Espagne) et précisions sur la systématique des involutinidés (Foraminifères). Rev. Paléobiol. 13, 1994.

Van der Zwan, C.J., Spaak, P., 1992. Iower to Middle Triassic sequence stratigraphy and climatology of the Netherlands, a model. Palaeogeogr. Palaeoclimatol. Palaeoecol. 91 277-290.

Warrington, G., Ivimey-Cook, H.C., 1992. Triassic. Atlas of Palaeogeography and Lithofacies: In: Cope,J.C.W., Ingham, J.K., Rawson, P.F. (Eds.), Mem. Geol Soc. Iondon, 13, pp. 97-106.

Warrington, G., Scrivener, R.C., 1990. The Permian of Devon, England. Rev. Palaeobot. Palynol. 66-3/4, 263-272.

Wolburg, J., 1968. Vom zyklischen Aufbau des Buntsandsteins. Neues Jb Geol. Paläontol. Mh. 9, 535-559.

Yu Jianxin, 2008. Floras and evolutionary dynamics across the Permian-Triassic boundary nearby the border ofGuishou and Yunnan, South China, Ph.D. thesis Univ. Paris 6 (France) and Univ. Wuhan (China).

Ziegler, A.M., Hulver, M.L., Rowley, D.B., 1997. Permian world topography and climate. In: Martini, 1.P. (Ed.), late Glacial and Post-Glacial Environmental Changes Quaternary, Carbonif erousPermian and Proterozoic. Oxford University Press, New York, pp. 111-146.

Ziegler, P.A., 1982. 3. Permo-Triassic development of Pangaea, In: Ziegler, P.A. (Ed.), Geological Atlas of Western and Central Europe, 1st edit. Shell Internationale Petroleum Maatsschappij B.V, The Hague, pp. 44-57.

Ziegler, P.A., 1990. 5. Permo-Triassic development of Pangaea. In: Ziegler, P.A., (Ed.), Geological Atlas of Western and Central Europe (2nd edit.). Shell Internationale Petroleum Maatsschappij B.V. and Geological Society of london, pp. 68-90. 